NBER WORKING PAPER SERIES

\title{
THE COMPETITIVENESS AND COMPARATIVE ADVANTAGE OF U.S. MULTINATIONALS, 1957-1983
}

Robert E. Lipsey

Irving Kravis

Working Paper No. 2051

NATIONAL BUREAU OF ECONOMIC RESEARCH 1050 Massachusetts Avenue

Cambridge, MA 02138

October 1986

The research reported here is part of the NBER's research program in International Studies. Any opinions expressed are those of the authors and not those of the National Bureau of Economic Research. 
NBER Working Paper \#2051

October 1986

The Competitiveness and Comparative Advantage of U.S. Multinationals, 1957-1983

\section{ABSTRACT}

The share in world exports of manufactured goods of U.S. multinational firms, Including their majority-owned overseas afflliates, has been nearly stable since 1966. This stability, over a period in which the export share of the U.S. as a geographical entity was declining for the most part, suggests that it was not declines in the competitiveness of American f1rms' management and technology that were responsible for the deterioration of the U.S. trade position. That view is reinforced by the fact that a good deal of the change in U.S. export shares can be explained by changes in U.S. prices relative to those of other countries.

The comparative advantage of both the U.S. and U.S. multinational flrms, espectally the latter, has been in chemicals, machinery, and transport equipment, Industries wh relatively fast growth in worldwide exports. The growth of U.S. exports in 1966-77 fell far short of what 1t would have been if the U.S. had retained its share in each industry. The growth of U.S. multinationals' exports fell a little short of that Implied by constant-shares but surpassed that of the U.S. as a country In almost every industry. After 1977, both the U.S. and 1ts multinationals kept up with their constant share growth rates and the U.S. even ran a bit ahead. The multinationals' position as exporters, now supplying almost half their exports from their majority-owned overseas affillates, seems to have been quite insulated from changes in U.S. policies and circumstances.

Robert E. Lipsey NBER

269 Mercer Street

New York, NY 10003
Irving B. Kravis Department of Economics 368 McNeil Building University of Pennsylvania Philadelphia, PA 19104 
THE COMPETITIVENESS AND COMPARATIVE ADVANTAGE OF U.S. MULTINATIONALS

$$
1957-1983 *
$$

Robert E. Lipsey and Irving B. Kravis

\section{Introduction}

In an earlier study it was shown that the share in world manufactured exports of firms located in the U.S. moved differently from the share of U.S. multinational firms, including both their domestic and their overseas operations. The U.S. share fell steadily from the 1950's through the mid-1970's, but the share of U.S. multinational firms did not decline at all or even increased (Lipsey and Kravis, 1985). That contrast suggests that it is important to distinguish between the factors that determine the competitiveness of the U.S. as a production location and those that determine the competitiveness of U.S. firms. The latter might include characteristics such as the firms' management and technology, since the firm characteristics would affect the firms' performance in both home and foreign operations.

Much of the standard analys is of trade developments explains increases or decreases in a country's exports and imports or shares in world trade by

*We are indebted for valuable comments and suggestions to the participants in a meeting at the National Science Foundation. Linda Molinari was responsible for much of the programming and statistical work and Rosa Schupbach and James Hayes for the preparation of the manuscript.

This research, part of the National Bureau's program in International Studies, was done mainly as a part of a study of the competitiveness of U.S. firms supported by a grant to the National Bureau from the National Science Foundation (PRA-8513944) and a grant to the University of Pennsylvania by the Ford Foundation (No. 855-0678). Some support was also received through the NBER's program on U.S. Trade Policy, Competitiveness, and Capital Mobility in the World Economy (NSF Grant No. PRA-8116459). Any opinions expressed are those of the authors and do not represent the $v$ iews of the National Bureau or of the sponsoring agencies. 
changes in the country's prices relative to those of its competitors and suppliers and by changes in incomes in its markets. That emphas is on price developments is the reason for the belief that the very high exchange value of the U.S. dollar was a major factor accounting for the large U.S. trade and current account deficits of recent years.

A rival explanation for U.S. trade difficulties that has been offered in recent years is that the problems are internal to U.S. firms; they have lost their technological lead or their management skills and, therefore, alterations in monetary and fiscal policies will not restore the competitiveness of the U.S. (See, for example, Abernathy et al., 1983). The decline of U.S. firms is seen as stemming from defects in the training of managers, from the emphasis in U.S. firms on short-term results, from the deterioration of technical education in this country, or from the declining U.S. lead in research and development investment.

Factors internal to firms are just the ones that have, in the last few years, become the main explanations for the phenomenon of direct investment. They are the elements of the competitiveness and comparative advantage of individual firms that enable them to produce in countries outside the ones where they originated in competition with local firms that have the advantage of familiarity with local product and factor markets and the favor of local governments. In the literature on multinationals (e.g., Dunning, 1981), these are treated as belonging to firms rather than to countries, and as being readily transferable from country to country within, but not between, firms. The more transferable these attributes are geographically, the less they can be the basis for national competitiveness and comparative advantage. 
to firm competitiveness and comparative advantage will not necessarily contribute to national competitiveness and comparative advantage. Subsidies to $R \& D$, to innovation, or to management or technical training may enhance the competitiveness of national firms in world markets, but that competitiveness may be exploited by producing outside the home country.

A corresponding implication is that the factors producing firm comparative advantages should be studied by examining measures of the competitiveness and comparative advantage of firms rather than that of their home countries. And any large difference between the fortunes of a country and those of the firms based in it helps us to determine whether the responsibility for changes lies with macroeconomic policy or with the determinants of firm advantages, such as management or technology.

\section{The Export Share of the U.S.}

Although our main interest in this paper is in the competitiveness of U.S. multinationals, we begin by examining, for comparison, developments in the competitiveness of the U.S. as a country. U.S. export shares of manufactured goods declined from the early or mid-1950's to the early or late 1970's, the date depending on the series used for measurement. The years 1976-78 were the lowest points so far in most series, and there was some recovery after that. Ratios for the years covered by surveys of U.S. investment abroad were as follows: 


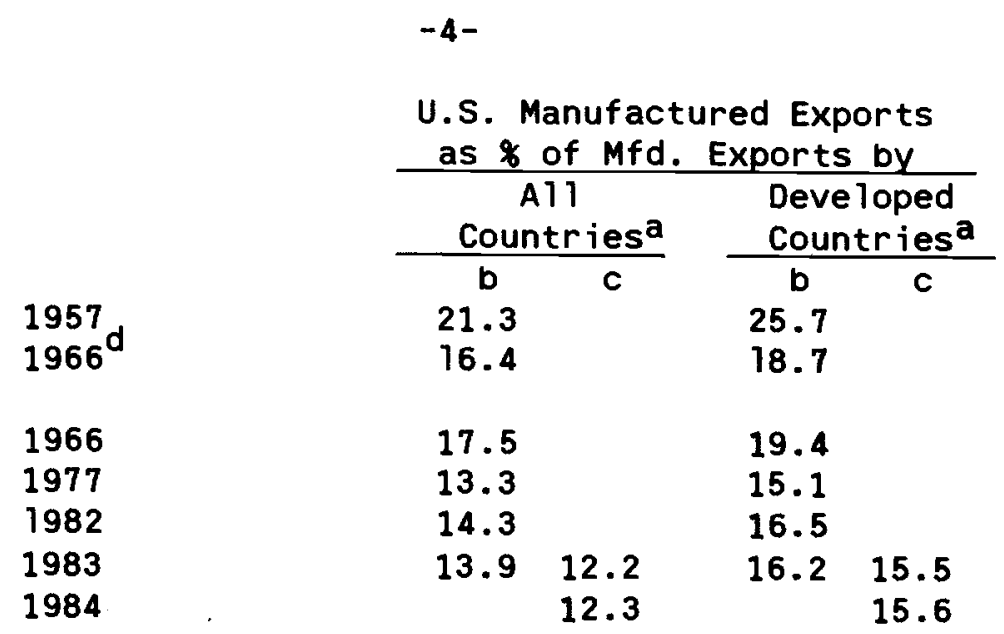

aThe terms "al1 countries," "World," "developed countries," and "LDCs" as used here and elsewhere in the paper refer to market economies only.

banufactured exports defined as in notes to Appendix Table U-1a, including manufactured foods and some items from SITC 9.

CSITC 5-8, excluding manufactured foods and some other output of manufacturing industries.

dComparable to 1957 .

Source: Appendix Tables $U-1$ and $U-1 b$.

The period from 1977 to 1982 saw a slight reversal of that trend, although it may turn out to be only a temporary one.

\section{The Role of Prices}

of the two broad explanations for changing export shares suggested above, we explore only very briefly here the role of prices. A measure of the change in U.S. prices relative to those of its main competitors, or what we might cal1 the price competitiveness of the U.S. is shown in Appendix Table U-16. It is an index of U.S. export prices relative to an index of world prices of manufactured exports, based on prices of the U.S. and of six main competitors, weighted by the importance of commodities in U.S. exports as described in 
Bushe, Kravis, and Lipsey (1986).

We ask first whether movements in the relative U.S. price level explain annual U.S. shares in exports of manufactures in the period from 1955 through 1983.

$$
\begin{aligned}
& \text { (1) } \log \text { USEXS }=3.30+0.99 \log \mathrm{PL}_{t}-1.08 \log \mathrm{PL}_{t-1}-0.19 \mathrm{~T} \quad \bar{R}^{2}=.96 \\
& \begin{array}{llll}
(12.03) & (8.57) \quad(19.41) & \text { DW } & =1.77
\end{array} \\
& \text { USEXS = U.S. exports of products in SITC 5-8 as per cent of exports } \\
& \text { by developed market economies. For period before 1965, } \\
& \text { shares in exports of SITC 5-8 are extrapolated back by } \\
& \text { shares in total exports (Appendix Table U-1b). } \\
& \mathrm{PL}=\text { Export Price index for the U.S. }(1975=100) \text { relative to } \\
& \text { export price index for } 7 \text { countries, including the U.S. } \\
& T=\text { time }
\end{aligned}
$$

Figures in parentheses are $t$ statistics

The export share of the U.S. as a country is explained by a downward trend and by the current and lagged price levels. The equation implies that a higher relative U.S. price level is associated with a higher U.S. export share the year it occurs but a lower share the year after. By the end of the year after the U.S. price increase, the U.S. export share would be below the one preceding the price rise.

A large part of the very high $\bar{R}^{2}$ in this equation is accounted for by the trend term. An alternative approach is to explain changes in the U.S. export share by changes in relative prices.

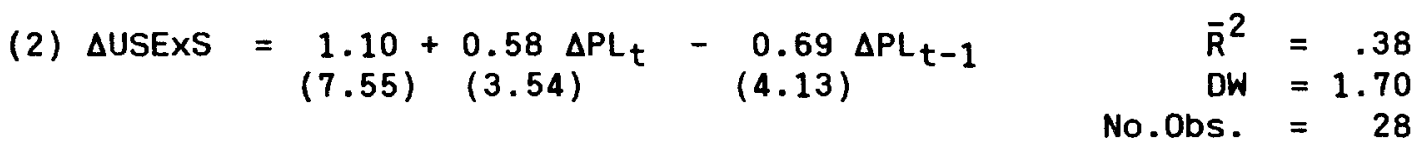

$$
\begin{aligned}
& \Delta=\text { variables in the form } x_{t} / x_{t-1}
\end{aligned}
$$

The equation, explaining a little more than a third of the variation in shares, again indicates that a rise in the relative U.S. export price first 
increases the U.S. export share in the year of the price increase and then reduces it the next year. The total decrease in share resulting from the price increase is about 11 per cent of the price change, implying a cumulative elasticity of substitution a little over one.

We can also test whether a high price level has any independent influence on changes in the U.S. export share aside from that of the price change

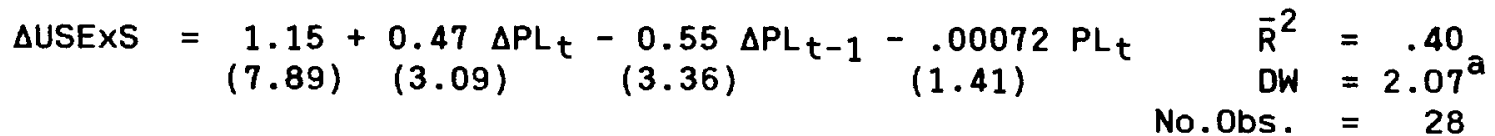

$$
\begin{aligned}
& { }^{a} \text { After correction for serial correlation }
\end{aligned}
$$

The price level coefficient is negative even when the current and lagged price changes are included in the equation, suggesting some additional unfavorable effects of high prices. However, the price level adds little to the explanation of trade shares once lagged price changes are included.

These results indicate that a good deal of the competitiveness of the U.S. as a country can be attributed to U.S. price levels and changes in them, relative to the rest of the world. Earlier work on machinery and transport equipment (Kravis and Lipsey, 1981, and Bushe, Kravis, and Lipsey, 1986) has suggested that a more thorough analysis would reveal still longer lags and price elasticities or substitution elasticities further above unity.

These export responses to price levels and price changes include the behavior of U.S. parent companies and must reflect their actions to a considerable extent, since they account for about two thirds of U.S. exports of manufactured goods. We now turn to the analysis of their exporting patterns. 


\section{The Competitiveness of U.S. Multinationals}

We saw earlier that the U.S. share in world manufactured exports declined between 1957 and 1966 from 21 or 22 per cent to 16-18 per cent. It then dropped to the 13 to 14 per cent range in 1977, where it remained in the early 1980 's. The figures are repeated in line 1 to make comparisons $w i t h$ the export record of multinationals easy.

\begin{tabular}{|c|c|c|c|c|}
\hline 1957 & 1966 & 1977 & 1982 & 1983 \\
\hline $21.3^{a}$ & $17.5^{b}$ & 13.3 & 14.3 & 13.9 \\
\hline $\begin{array}{l}\text { NA } \\
5.8 \mathrm{a}\end{array}$ & $\begin{array}{r}11.0 \\
8.2 \mathrm{~d}\end{array}$ & $\begin{array}{l}9.2 \\
9.7\end{array}$ & $\begin{array}{l}9.5 \\
9.7\end{array}$ & $\begin{array}{r}9.1 \\
10.0\end{array}$ \\
\hline NA & 17.7 & 17.6 & 17.7 & 17.7 \\
\hline
\end{tabular}

a Not comparable with later years

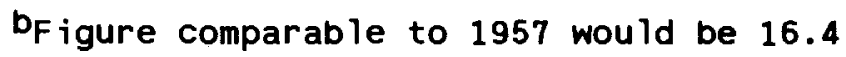

CExports by majority-owned foreign affiliates (MOFAs) as per cent of exports by all countries except the U.S.

dFigure comparable to 1957 would be 7.9

Source: Appendix Table U-1

It can be seen (line 4) that the overall share of U.S.-based multinationals, including exports by parents and majority-owned affiliates (MOFAs), 1 was essentially stable. Exports from the U.S. by multinational parents shared, though to an attenuated degree, the decline between 1966 and 1977 in total U.S. exports. However, the growth of affiliate exports more than offset this decline.

Exports by parent firms from the U.S., after declining as a share of

1Export data are not available for minority-owned affiliates. If it is assumed that their exports were the same percentage of sales as for MOFAs in the same industry and country or region, the export shares including them would be as follows (Table $U-1$ ): 
$-8-$

world and developed-country exports between 1966 and 1977, varied within fairly narrow ranges:

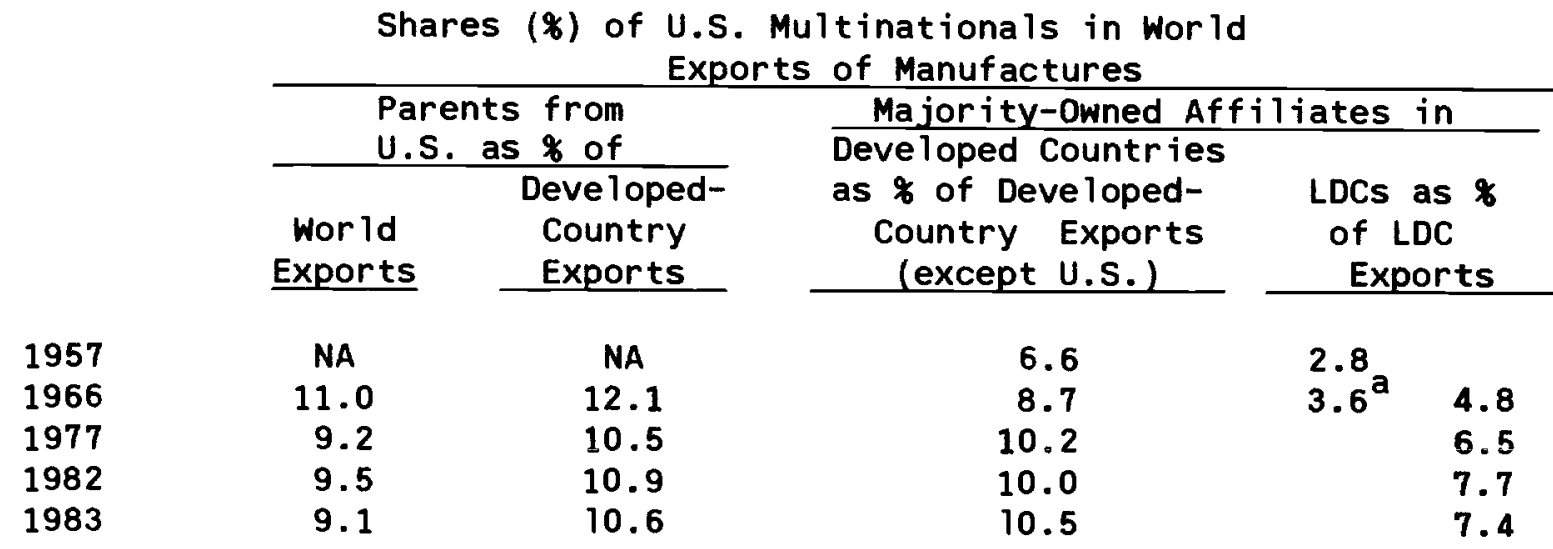

${ }^{a}$ Comparable to 1957

Source: Appendix Table U-1

As is implied by the fact that parent export shares declined less than those of the U.S. as a whole, the share of parent firms in U.S. exports of manufactures rose substantially between 1966 and 1977 . Some of that rise was lost between 1977 and 1982 .

\begin{tabular}{l} 
Parent Firm Share (\%) \\
in U.S. Exports \\
\hline
\end{tabular}

1966

1977

1982

1983
62.7

69.4

66.2

65.2

Source: Appendix Table U-1

That increased importance of multinational firms as exporters from the U.S. in 1966-77 was apparently not the result of a shift of firms from non- 
multinational to multinational status. In fact, the number of firms reporting as multinationals actually decreased slightly from 1966 to 1977 , as can be seen in Appendix Table U-10. However, in the period when the multinationals' share decreased, between 1977 and 1982, there was a substantial decline in the population of U.S. multinational firms. 2

The shares of majority-owned affiliates in exports of both developed and LDC host countries shows a pattern of sharp increases and, for developed countries, rough stability since 1977. The MOFA share in exports of developed countries increased by more than 50 per cent in the 20 years before 1977 and then remained fairly stable through 1983. And the share of U.S. affiliates in LDC exports grew by almost 75 per cent from 1957 through 1977 at a time when the share of these countries in world exports was also increasing substantially, 3 and continued to rise at least through 1982 . Thus, in both developed and less developed host countries, there was a period of active development in which the majority-owned affiliates outpaced other host-country

\footnotetext{
2Part of this reduction in population may be illusory and the growth of parent exports therefore understated. The cutoff point below which full data for affiliates did not have to be reported was increased from $\$ 500,000$ in 1977 to $\$ 3$ million in 1982 . Any parent firm with no affiliates above the cutoff size was exempt from reporting on its own activities. We were able to make an adjustment, quite small, for the effect of this change on affiliate exports, but we are not able to guess the effect on parent exports or other parent variables. The impact on aggregate affiliate measures is limited by the unimportance of affiliates of that size in the totals, but it is conceivable that quite large parents with only marginal overseas production were eliminated from the list even without making any changes in their overseas activities. Thus, we do not know what the decline in parents' share of U.S. exports represents. It could be mostly a statistical artifact, it could represent a turning away from multinationality by U.S. firms, or it could represent a decline in the competitiveness of U.S. multinationals relative to other U.S. firms, or a shift in U.S. comparative advantage away from industries in which U.S. multinationals have their advantages. A conclusion on this issue requires disaggregation by industry and the study of fixed groups of firms.

${ }^{3}$ This result seems to contradict the findings of a paper by Nayyar (1978) to the effect that the share of U.S. majority-owned affiliates in developingcountry exports fell from about 10.6 per cent to below 9 per cent in the early 1970 's. The growth of affiliate exports to 1974 in Nayyar's data seems very
} 
firms, followed by a period of less dynamic growth (for both the countries and the affiliates), in which the affiliates' exports increased in step with those of other host-country firms.

As is implied by what has been said about parents and affiliates, majority-owned overseas affiliates' shares in exports by U.S. multinationals jumped substantially from 1966 to 1977 , and their share of exports by all U.S. firms more than doubled from 1957 to 1977 . Then the affiliates' share decreased slightly between 1977 and 1982 before increasing again, to its highest recorded level, in 1983 .

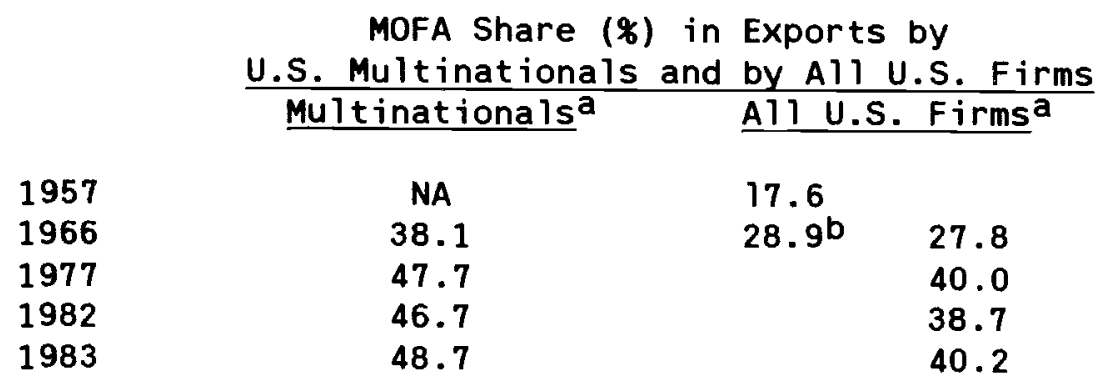

ancludes exports of MOFAs

bComparable to 1957

Source: Appendix Table U-1

That switch in the 1977-82 period suggests a move by U.S. multinational firms toward producing in the U.S., perhaps as a response to the low values of the U.S. dollar in the late 1970's and early 1980's, before shifting back toward foreign production as the dollar recovered.

To what may the superior foreign export performance of U.S.-controlled firms be attributed? Several possibilities suggest themselves. One is that

slow in view of our 1977 census total. Furthermore, he defined aggregate developing country manufactured exports much more narrowly than in our calculations. 
American affiliates were sharing in the superior (to the U.S.) export growth of their host countries. This would involve behavior like that of other domestic firms in the host countries. Another is that U.S. parents systematically shifted export operations to foreign bases through diminution or slower growth in U.S. exports. Perhaps in the end the basic factors underlying export sourcing decisions are not very different for these two possible explanations. However, if U.S. affiliate exports merely kept pace with the rate of growth in host country exports, there may be a stronger presumption that the ME was simply responding to the host country's competitive opportunities. Affiliate export performance in host countries superior to that of both local firms and U.S. parents, on the other hand, suggests an active policy of shifting exports and a role in promoting host-country export growth.

\section{The Comparative Advantage of U.S. Multinationals}

Before examining how different industries contributed to these changes in exports and export shares we use the distribution of exports among industries to identify the comparative advantage of the United States and of its multinational firms. We identify the comparative advantage in terms of the relative distributions of exports. U.S. multinationals, for example, are regarded as having a comparative advantage in the chemical industry relative to the U.S. as a country (or to the world as a whole), if the share of chemicals in their exports is larger than the share of chemicals in U.S. (or world) exports. It would be desirable to use net exports as the criterion for countries, but we have not so far made such calculations for the multinationals, and it is also not as clear for them what the figures would mean. One reason for the uncertainty is that their exports are classified by industry rather than by pro- 
duct, and while we consider it reasonable to assume that their exports are within that industry, the assumption that their imports were also in the same industry would be more questionable. Another drawback to this method of assessing comparative advantage is that it ignores distortions in the composition of trade due to government interventions.

The differences between the distributions of U.S. and U.S. multinationals' exports and those of the world and of developed countries in 1966, the first year for which all are available, are given below. They show that the U.S. had comparative advantages relative to the world in chemicals, machinery, particularly non-electrical, and transport equipment. U.S. multinational firms' comparative advantage ran along the same lines, but to an exaggerated degree. Their concentration in chemicals and machinery was slightly greater than that of the U.S. and in transport equipment, much greater, while they exported a smaller proportion of foods, metals, and other manufactured products.

Differences Between Industry Distributions of Exports by the U.S. and U.S. Multinationals and Those of the Wor $1 d^{a}$ and Developed Countries ${ }^{b}$ in 1966

\begin{tabular}{|c|c|c|}
\hline $\begin{array}{l}\text { industry Share }(\xi) \text { ir } \\
\text { U.S. Exports minus } \\
\text { Ind. Share of }\end{array}$ & $\begin{array}{l}\text { Industry Share }(\%) \text { in } \\
\text { U.S. Mult inat. Exports } \\
\text { minus Ind. Share of }\end{array}$ & $\begin{array}{l}\text { Industry Share (\%) in } \\
\text { U.S. Multinationals' } \\
\text { Exports minus }\end{array}$ \\
\hline $\begin{array}{cc}\text { Wevelope } \\
\text { World } & \begin{array}{c}\text { Develo } \\
\text { Countrie } \\
\text { Exports }\end{array} \\
\end{array}$ & $\begin{array}{l}\text { Developed } \\
\text { Countries } \\
\text { Exports } \\
\end{array}$ & $\begin{array}{l}\text { Industry Share } \\
\text { in U.S. Exports }\end{array}$ \\
\hline
\end{tabular}

$\begin{array}{lrrrrr}\text { Foods } & -4.3 & -.9 & -7.3 & -3.8 & -3.0 \\ \text { Chemicals } & 2.4 & 1.7 & 3.0 & 2.2 & .5 \\ \text { Metals } & -3.6 & -3.2 & -8.2 & -7.8 & -4.6 \\ \text { Machinery } & 8.0 & 6.0 & 8.8 & 6.8 & .8 \\ \quad \text { Non-elect. } & 6.9 & 5.5 & \text { NA } & \text { NA } & \text { NA } \\ \text { Electrical } & 1.1 & .5 & \text { NA } & \text { NA } & \text { NA } \\ \text { Transp. Equip. } & 5.8 & 4.5 & 14.0 & 12.7 & 8.2 \\ \text { Other Mfg. } & -8.3 & -8.1 & -10.2 & -10.1 & -2.0\end{array}$

$a_{A 1} 1$ market economies $b_{\text {Developed market economies }}$ Source: Appendix Table U-9 
The corresponding comparisons for 1982 show a similar pattern for the U.S. However, there were some shifts. The U.S. had less of a comparative advantage in chemicals and transport equipment and more in non-electrical machinery, and larger disadvantages in metals. The breakdown of transport equipment into motor vehicles and equipment and other transport equipment reveals that the U.S. comparative advantage was in the latter subgroup, mainly aircraft and parts. In motor vehicles the U.S. showed comparative disadvantages relative to the world and to developed countries as a group.

Differences Between Industry Distributions of Exports by the U.S. and U.S. Multinationals and Those of the World $\mathrm{d}^{\mathrm{a}}$ and of Developed Countries ${ }^{b}$ in 1982

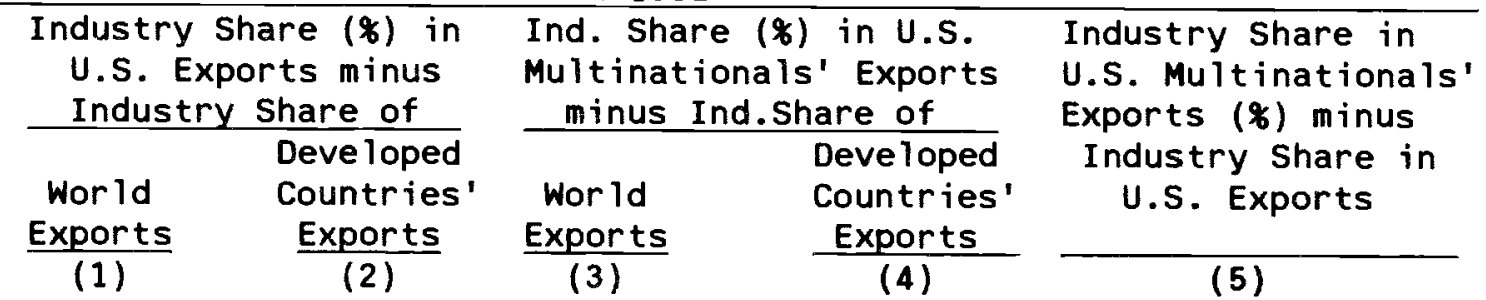

(4)

$\begin{array}{lrrrrr}\text { Foods } & -3.2 & -1.5 & -5.4 & -3.6 & -2.1 \\ \text { Chemicals } & 1.5 & .9 & 5.1 & 4.4 & 3.6 \\ \text { Metals } & -4.5 & -4.7 & -6.9 & -7.1 & -2.4 \\ \text { Machinery } & 10.1 & 8.7 & 7.6 & 6.2 & -2.5 \\ \quad \text { Non-elect. } & 9.0 & 7.6 & 3.9 & 2.5 & -5.1 \\ \quad \text { Electrical } & 1.0 & 1.1 & 3.7 & 3.8 & 2.6 \\ \text { Transp. Equip. } & 2.8 & 1.2 & 10.0 & 8.4 & 7.1 \\ \quad \text { Motor vehicles } & -1.2 & -2.5 & 7.7 & 6.4 & 8.9 \\ \quad \text { Other transp. } & & & & & -1.8 \\ \quad \text { equip. } & 4.0 & 3.8 & 2.2 & 2.0 & -3.7 \\ \text { Other Mfg. } & -6.8 & -4.7 & -10.4 & -8.4 & \end{array}$

$a_{A 11}$ market economies beveloped market economies Source: Appendix Table U-9.

For U.S. multinational firms, a finer breakdown by industry for 1982 than was available for 1966 reveals that they possessed comparative advantages relative to the world as a whole and to developed countries in both electrical and nonelectrical machinery. Largely, the industry pattern of their comparative 
advantage was similar in 1982 to the earlier one, with some shift towards chemicals and a large decline in the ir comparative advantage in transport equipment. The breakdown of the transport equipment industry into the two subgroups indicates that U.S. multinationals held comparative advantages in both, and that the margins were larger for motor vehicles than for other transport equipment.

The 1982 comparison between U.S. multinationals and the U.S. as a country (Col. 5) shows that the multinationals' comparative advantage in machinery relative to that of other U.S. firms had disappeared; the U.S. as a production location showed a large comparative advantage relative to U.S multinationals, although the latter enjoyed a smaller, but noticeable, comparative advantage in electrical machinery relative to the U.S. The multinationals, by 1982 , had increased their advantage in chemicals but reduced that in transport equipment relative to the U.S. Within transport equipment, U.S. multinationals had a large comparative advantage in motor vehicles relative to the U.S. but the U.S. as a country had a noticeable comparative advantage in other transport equipment relative to U.S. multinationals. The contrast reflects the fact that the motor vehicle industry is one of the most multinational of U.S. industries in its operations, in the sense that a high proportion of its employment is overseas (Kulchycky and Lipsey, 1984, p. 2) and it does much of its exporting from abroad, while the other transport equipment industry is among the least multinational and does most of its exporting from the U.S. Even among parent firms, other transport equipment companies have smal1 proportions of their employment abroad relative to parents in other industries, and tend to fill export demand from the U.S.

The differences between the comparative advantages of the U.S. and of U.S. 
multinationals would show up more strongly if we compared the multinationals, or the parent companies themselves, with non-multinational U.S. companies. However, that comparison is difficult because of incompatabilities in the classification of exports between the product classification for the U.S. and the industry classification we used for the multinationals. That problem is obvious in industries such as chemicals and electrical machinery that are almost completely dominated by multinationals, as can be seen in Appendix Table U-3. where estimated electrical machinery industry exports from the U.S. by U.S. multinational parents and foreign-owned firms in the U.S. are larger than total U.S. exports of electrical machinery. ${ }^{4}$ It is clear, in any case, that U.S. parents possess large comparative advantages relative to non-multinational U.S. firms in chemicals and electrical machinery, but that the non-multinational firms have a strong comparative advantage in non-electrical machinery.

A different set of observations on the comparative advantage of the U.S. and of U.S. multinationals can be made by comparing U.S. firms in general and U.S. parents with foreign-owned firms in the U.S. In this case we are comparing U.S. firms not with foreign countries in general but with foreign multinationals, holding constant the production conditions of the U.S.

\footnotetext{
${ }^{4}$ The problem is not only one of product and industry classification but also reflects the fact that there is some duplication between the firms listed as U.S. multinationals and those listed as foreign-controlled U.S. firms.
} 
Differences Between Industry Distributions of Exports

by Foreign Multinationals Operating in the U.S. and Those of the U.S. and of U.S. Parents

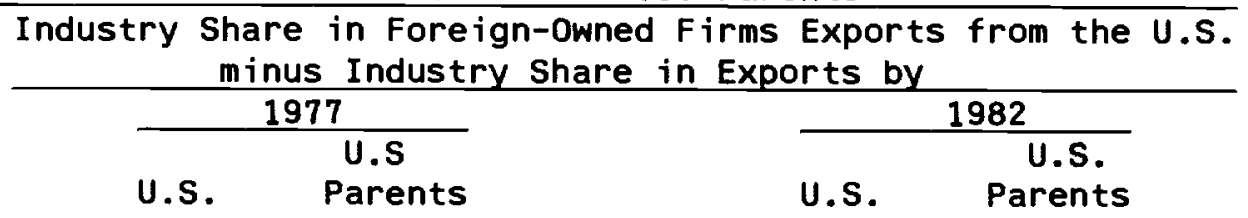

$\begin{array}{lrrrr}\text { Foods } & 1.6 & 5.1 & -2.1 & .9 \\ \text { Chemicals } & 15.7 & 13.8 & 23.3 & 21.5 \\ \text { Metals } & 4.6 & 5.6 & 1.0 & 2.2 \\ \text { Machinery } & & & & -3.5 \\ \quad \text { Non-elec. } & -1.2 & .8 & -8.4 & -3.5 \\ \quad \text { Electrical } & 1.2 & -.6 & -3.3 & -15.6 \\ \text { Transport Equip. } & -23.0 & -29.1 & -6.6 & -2.3 \\ \text { Other Mfg. } & 1.2 & 4.3 & & \end{array}$

Source: Appendix Table U-8

Data on exports by foreign-owned firms in the U.S. are not available for 1966 but we can make the comparisons for 1977 and 1982 . The earlier year may be affected by the fact that many of the foreign-owned operations were new or had been foreign-owned for only a short time.

The most striking characteristic of the exports by foreign-owned U.S. firms in 1977 was the high concentration in chemicals, mainly by German multinationals, and the absence of exports of transport equipment, both areas of U.S. and U.S. firms' comparative advantage. The concentration of exports by the foreign multinationals in chemicals increased substantially between 1977 and 1982. Thus, although chemicals was an industry of U.S. and U.S. multinationals' comparative advantage relative to the rest of the world, there are indications that at least German multinational firms possessed greater firm-specific advantages in this area. The comparative disadvantage of foreign multinationals in transport equipment was still large in 1982 but had diminished greatly, especially relative to the U.S. in general. 


\section{Competitiveness Within Industry Groups}

The decline in the competitiveness of the U.S. relative to other developed countries and to the world between 1966 and 1982, as manifested in its falling shares of exports, was spread across all the major industry groups.

Changes in U.S. Shares of World and Developed-Country Exports of Manufactures $1982 / 1966$

\begin{tabular}{cc}
\hline Wor $1 d^{\mathrm{a}}$ & $\begin{array}{c}\text { Developed } \\
\text { Country }\end{array}$ \\
\cline { 2 - 2 } .82 & .77 \\
.75 & .79 \\
.69 & .68 \\
.84 & .90 \\
.90 & .93 \\
.78 & .88 \\
.67 & .76 \\
.86 & .98 \\
.81 & .85
\end{tabular}

Food and Kindred Products Chemicals and Allied Products .81 .85

${ }^{a}$ A1 l market economies

${ }^{b}$ Developed market economies Source: Appendix Table U-7

However, it was smaller in non-electrical machinery than in the other groups. Relative to developed countries, the decline was smaller in the whole machinery industry than in any of the others except miscellaneous manufactures.

As we know from the aggregate data presented earlier, the story was quite different for the worldwide operations of U.S. multinationals, including those of parents and their majority-owned affiliates. 


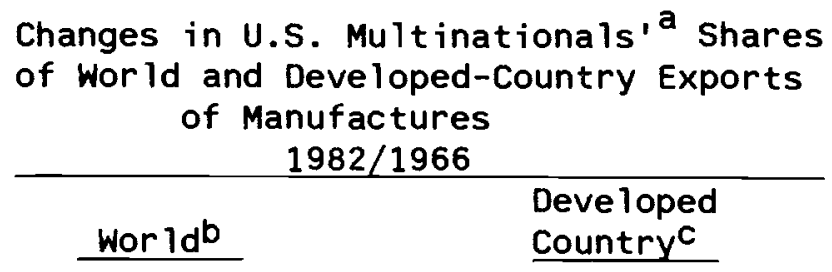

Foods and Kindred Products

1.04

1.08

Chemicals and Allied Products

1.11

1.17

Metals

Machinery

Non-electrical

Electrical

Transport Equipment

.94

.97

.92

.90

NA

NA

NA NA

Other Mfg.

A11 Mfg.

.99

1.01

aparents and majority-owned affiliates

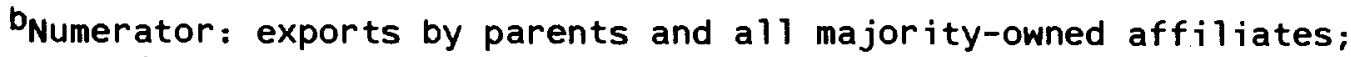

Denominator: exports from all market economies.

$\mathrm{C}_{\text {Numerator }}$ exports by parents and majority-owned affiliates in developed market economies; Denominator: exports from developed market economies.

Source: Appendix Table U-7

U.S. multinationals gained in world export shares in food and chemicals and lost shares in the other industries. Even where their world shares declined, they held up better than those of the U.S. as a country. That relationship can be seen clearly in the ratio of the export share changes for U.S. multinationals to those for the U.S. as a country. 
Changes in U.S. Multinationals' Export Shares Relative to those in U.S. Export Shares $1982 / 1966$

Shares in Shares in Developed Wor ld Exports Country Exports

Food and Kindred Products Chemicals and Allied Products Metals Machinery

Transport Equipment

Other Mfg.

Total Mfg.

$\begin{array}{ll}1.27 & 1.40 \\ 1.48 & 1.48 \\ 1.36 & 1.43 \\ 1.10 & 1.00 \\ 1.18 & 1.07 \\ 1.09 & 1.07\end{array}$

1.22

1.19

Source: Previous two text tables

On the average, U.S. multinationals' export shares increased more or decreased less than those of the U.S. by a margin of about 20 per cent. In no industry group did they lose relative to the U.S. as a whole, but in machinery the growth of their exports from developed countries just kept pace with that of the U.S.

In the case of machinery, both U.S. multinationals and the U.S. as a country lost ground, but neither by much. In the case of transport equipment, both the U.S. as a country and U.S. multinationals lost export shares by around a quarter of the 1966 level.

\section{Comparative Advantage, Growth in Demand, and Overa11 Competitiveness}

Changes in the overall competitiveness of a country or of its multinational firms can be factored into several elements. One is the set of changes in competitiveness within industries. A second is their comparative advantage, which determines the extent to which they produce and export in each industry. And a third is the rate at which world trade grows in each industry. The last is partly a reflection of the rate of growth of demand and partly a result of 
shifts in the degree to which demand is met by each country's local output in each industry. The first two of these elements have already been touched upon.

The third element has varied a good deal among industries. In the whole period covered, and in each of the sub-periods, world exports of chemicals, electrical machinery, and transport equipment grew more rapidly than manufactured exports in general, while exports of foods and metals grew less and those of non-electrical machinery and other manufacturing clustered close to the average.

\begin{tabular}{lcr} 
Growth in Exports $^{\mathrm{a}}$ & $\begin{array}{c}\text { Ey Market } \\
\text { Economies }\end{array}$ \\
\hline$\frac{1977}{1966}$ & $\frac{1982}{1977}$ & $\frac{1982}{1966}$ \\
& & \\
4.67 & 1.40 & 6.54 \\
5.72 & 1.72 & 9.86 \\
4.62 & 1.49 & 6.87 \\
5.94 & 1.67 & 9.91 \\
5.34 & 1.64 & 8.78 \\
7.16 & 1.71 & 12.21 \\
6.82 & 1.55 & 10.56 \\
5.21 & 1.55 & 8.10 \\
& & \\
5.49 & 1.57 & 8.63
\end{tabular}

Food and Kindred Products Chemicals and Allied Products Metals

Machinery Non-electrical

Electrical

Transport Equipment

Other Mfg.

1.57

Total Mfg.

aThese are values and are affected, of course, by differences among industry groups in price changes as we 11 as in quantity changes. Figures are ratios of terminal-year to initial-year values.

Source: Appendix Table U-6

Both the U.S. and U.S.-owned multinational firms were oriented toward the faster-growing industries in this breakdown, with their below-average weighting of foods and metals and high weights for chemicals, machinery, and transport equipment. This was even more the case for the U.S. multinationals than for the U.S. Thus, if the U.S. and its multinational firms had retained 
their shares of exports within these industry groups, their shares of aggregate manufacturing exports would have increased.

We can compare the actual changes in U.S. and U.S. multinational firms exports with those that would have occurred if they had retained their 1966 shares within industries. We refer below to this calculated export growth as "constant share" export growth.

The bias of the U.S. and U.S. multinationals toward fast-growing industry groups is indicated by their high "constant share" growth rates, a little higher for the multinationals than for the U.S. but both above the world growth rate. Actual U.S. exports fell far short of that hypothetical growth and the export growth of multinationals fell short as well, although not by as much. That means that the stability in the U.S. multinationals' share of world exports was the result of a combination of declining shares within at least some industry groups with an orientation toward the faster-growing industries.

\begin{tabular}{c}
$\begin{array}{r}\text { Growth of Manufactured Exports, } \\
\text { Actual } \\
\text { and Constant Share } \\
1982 / 1966\end{array}$ \\
\hline Actual
\end{tabular}
Al1 market economies
8.63
U.S.
7.02
8.99
U.S. multinationals
8.59
9.37

Source: Export growth from preceding text table; distributions of exports from Appendix Tables $U-3, U-5$, and $U-6$.

If we divide the whole period into two parts, we get the following comparison: 


\begin{tabular}{|c|c|c|c|}
\hline \multicolumn{2}{|c|}{$1977 / 1966$} & \multicolumn{2}{|c|}{$1982 / 1977$} \\
\hline Actual & $\begin{array}{c}\text { Constant } \\
\text { Share } \\
\end{array}$ & Actual & $\begin{array}{c}\text { Constant } \\
\text { Share } \\
\end{array}$ \\
\hline $\begin{array}{l}5.49 \\
4.16 \\
5.43\end{array}$ & $\begin{array}{l}5.65 \\
5.87\end{array}$ & $\begin{array}{l}1.57 \\
1.69 \\
1.58\end{array}$ & $\begin{array}{l}1.59 \\
1.60\end{array}$ \\
\hline
\end{tabular}

In the decade from 1966 to 1977 , the comparative advantage of both the U.S. and U.S. firms favored above-average export growth, given the rates of growth of the seven industry groups. The prospective margin in the constant-share growth ratio for the U.S. was .16 over the world growth ratio and for U.S. multinationals the margin was .38. In actuality the U.S. fell far below the hypothetical constant share growth rate and far below the world growth rate despite its favorable composition of exports. U.S. multinationals' exports grew at close to the world rate because their export composition was favorable, and the favorable export mix made up for the loss of shares within groups.

Given the industry growth rates over the next five years, the U.S. and U.S. multinational firm export mixes in 1977 would have produced roughly constant shares in total manufactured exports. In fact, U.S. exports grew at a little more than both the world rate and their constant share rate. For U.S. multinationals, actual export growth was close to the world rate, as in the earlier period. However, their growth was below the U.S. rate, as had not been the case for the earlier decade.

If the composition of exports in 1966 had been that of 1982 for the U.S., U.S. multinationals, and the world, and if the industry export growth rates of the 1966-1982 period had been as they were, the comparisons would have come out as follows: 
Constant Share Export Growth, 1982/1966 Assuming 1966 and 1982 Industry Distribution of Exports 1966

Export Dist.

U.S.

U.S. multinationals

All market economies
8.99

9.37

8.63 1982

Export Dist.

Source: World exports from Table U-6.

In 1982, the U.S. multinationals continued to show the greatest bias toward what had been the fast-growing export sectors of 1966-1982. That bias was stronger than that of the U.S., which was, in turn, more oriented to such sectors than was the world as a whole. However, the rest of the world moved toward the rapidly growing export industries a little faster than either the U.S. as a country or U.S. multinationals.

\section{Conclusion}

The worldwide share of U.S. multinational firms (U.S. parent companies plus their majority-owned affiliates) in manufactures exports has been nearly stable since 1966 . We do not know what happened to parent exports from the U.S. before 1966, but the very large growth in affiliate exports makes it probable that the total share of U.S. multinationals increased between 1957 and 1966. The early growth $(1957-66)$ and later stability (1966-77) of overall U.S. multinational export shares occurred while the share of the U.S. as a geographical location declined substantially, from over 20 per cent to 13 or 14 per cent. Since 1977, there have been no clear trends in the shares of all U.S. firms, of parents, and of majority-owned affiliates in the aggregate, although the affiliate share continued to increase in developing countries. Thus, U.S. multinationals conformed to the market performance of local firms, 
both in the U.S. and in developed countries abroad during these years. This is in contrast to their rapid expansion of exports prior to 1977 . In those years, they increased their exports from virtually all foreign locations at a faster rate than other host-country firms, and their exports from the U.S. faster than non-multinational U.S. firms.

This record is consistent with the view that American management and technology remained competitive, and is at variance with the argument sometimes made that the fall in the share of the U.S. in world manufactures exports was due to management failures and declines in technology. Perhaps the greater integration of the world economy with respect to transport and communications, and hence to the ease of managerial control over activities in distant locations, facilitated the expansion of affiliate exports in the 1957-77 period, but even so, American management should be credited with taking advantage of these opportunities. And since 1977, American-controlled firms abroad have maintained their shares in a rapidly growing world market, with powerful competition from Japan and some other industrial countries and the advent of new competitors.

While we do not attempt to explain fully the decline in the U.S. country share in export markets, we find that a substantial part of the changes in share during a thirty-year period could be accounted for by movements in U.S. export prices relative to those of its main competitors. That finding is further evidence, in our view, that much of the explanation for the export performance of the U.S. as a geographical entity must be looked for in the factors that determine price levels. Over the short run, at least, these are presumably monetary, fiscal, and related policies that affect exchange rates and rates of inflation.

The loss of U.S. shares between 1966 and 1982 extends to each of the major branches of manufacturing. The shares of U.S. multinationals, however, 
increased in foods, chemicals, and, relative to developed countries, in other manufactures. They also showed smaller declines than those of the U.S. in most other categories.

The comparative advantage of the U.S. has been in chemicals, machinery, and transport equipment, and this is even more true for U.S. multinationals. These have been fast-growing exports in world markets. They contributed substantially to an export composition weighted in favor of products with relatively strong demand growth. However, the growth of manufactures exports between 1966 and 1977 by all firms located in the U.S. fell short, by almost a third, of what it would have been if the U.S. had maintained a constant share in each industry and thus participated proportionately in the expansion of world trade in each industry. The exports of U.S. multinationals also fell short of constant-share growth, but by less than 10 per cent. Between 1977 and 1982, in contrast to the earlier period, the export growth implied by constant shares for the U.S. and for U.S. multinationals was close to the world and developed-country averages. That is, the composition of exports for both was a little less favorable relative to other countries than it had been before. The growth in U.S. exports in those years was close to or even slightly greater than would have been produced by constant 1977 shares in each industry, while that of U.S. multinationals was slightly less. Thus, in the latest period for which we have data, when U.S. exports kept pace with those of other countries, as they had failed to do in the preceding quarter-century, the differentiation between U.S. multinationals and the U.S. as a country was great ly reduced.

The major conclusion about U.S. multinationals is that they have continued to hold a very steady share in world exports. That has been true while the 


$$
-26-
$$

U.S. country share was declining and it remained true when U.S. country share rose. The multinationals position in exports thus seems to have been quite insulated from changes in home-country policies or circumstances. 
List of References

Bach, Christopher L. (1984), "U.S. International Transactions, Fourth Quarter and Year 1983," Survey of Current Business, Vol. 64, No. 3, March.

(1986), "U.S. Internationa1 Transactions, Fourth Quarter and Year 1985," Survey of Current Business, Vo1. 66, No. 3, March.

Bame, Jack J. (1973), "U.S. Balance of Payments Developments: First Quarter 1973," Survey of Current Business, Vol. 53, No. 6, June.

Bushe, Dennis M., Irving B. Kravis, and Robert E. Lipsey (1986), "Prices, Activity, and Machinery Exports: An Analysis Based on New Price Data," Review of Economics and Statistics, Vol. LXVIII, No. 2, May, pp. 248-255.

Di Lullo, Anthony J. (1985), "U.S. International Transactions, Third Quarter 1985," Survey of Current Business, Vol. 65, No. 12, December.

Howenstine, Ned G. (1985), "U.S. Affiliates of Foreign Companies: Operations in 1983," Survey of Current Business, November, pp. 36-50.

Kravis, Irving B. and Robert E. Lipsey (1982), "Prices and Market Shares in the International Machinery Trade," Review of Economics and Statistics, Vo1. LXIV, No. 1, February, pp. 110-116.

(1986), "The Assessment of National Price Levels," NBER Working Paper 1912, May.

Krueger, Russe11 C. (1983), "U.S. International Transactions, First Quarter 1983," Survey of Current Business, Vol. 63, No. 6, June.

Kulchycky, Ksenia and Robert E. Lipsey (1984), "Host-Country Regulation and Other Determinants of Overseas Operations of U.S. Motor Vehicle and Parts Companies," NBER Working Paper 1463, September.

Lipsey, Robert E. and Irving B. Kravis (1985), "The Competitive Position of U.S. Manufacturing Firms," Banca Nazionale del Lavoro Quarterly Review, June.

Nayyar, Deepak (1978), "Transnational Corporations and Manufactured Exports from Poor Countries," Economic Journal, March, pp. 59-84.

Parrish, Evelyn M. (1974), "U.S. Balance of Payments Developments: First Quarter 1974," Survey of Current Business, Vol. 54, No. 6, June. 
United Nations (1958), Commodity Trade Statistics, Jan.-Dec. 1957, Statistical Papers, Series D, Vol. VII, No. 4. (1963), Monthly Bulletin of Statistics, March. (1965?), Statistical Yearbook, 1963. (1972a), Monthly Bulletin of Statistics, April. (1972b), Monthly Bulletin of Statistics, July.

U.S. Bureau of the Census (1985), "Reconciliation of 1984 U.S.-Canadian Merchandise Trade Statistics," Release, June 12.

U.S. Department of Commerce (1960), U.S. Business Investments in Foreign Countries, by Samuel Pizer and Frederick Cutler, Office of Business Economics.

(1973a), The Reconciliation of U.S.-Canada Trade Statistics, 1970, A Report by the U.S.-Canada Trade Statistics Committee.

(1973b), "The Reconciliation of U.S.-Canada

Trade Statistics: 1971 and 1972," Release, December.

(1975), U.S. Direct Investment Abroad, 1966,

Bureau of Economic Analysis.

(1976), Foreign Direct Investment in the United States, Report to the Congress, Vol. 2: Report of the Secretary of Commerce: Benchmark Survey, 1974. Bureau of Economic Analysis.

(1981), U.S. Direct Investment Abroad, 1977,

(1983), Foreign Direct Investment in the

United States, 1980, 0ctober.

(1985a), U.S. Direct Investment Abroad: 1982

Benchmark Survey Data, Bureau of Economic Analysis, December.

(1985b), U.S. D1rect Investment Abroad:

Operations of U.S. Parents and their Foreign Affiliates, Preliminary 1983 Estimates, Bureau of Economic Analysis, December.

(1985c), Foreign Direct Investment in the U.S.: Operations of U.S. Affiliates, 1977-80, Bureau of Economic Analysis.

(1985d), Foreign Direct Investment in the U.S.: Operations of U.S. Affiliates of Foreign Companies, Revised 1982 Estimates, Bureau of Economic Analysis, December.

(1985e), Foreign Direct Investment in the U.S.: Operations of U.S. Affiliates of Forelgn Companies, Preliminary 1983 Estimates, Bureau of Economic Analysis, December. 


\author{
Appendix Table U-1 \\ Indicators of the Shares of the U.S., U.S. Firms, and U.S. Multinational \\ Enterprises in World Exports of Manufactured Goods \\ $1957,1966,1977,1982$, and 1983
}

\begin{tabular}{|c|c|c|c|c|c|}
\hline & $\frac{1}{\text { Compa }}$ & le to & & & \\
\hline 1957 & 1957 & $\begin{array}{l}\text { Later } \\
\text { Years }\end{array}$ & 1977 & 1982 & 1983 \\
\hline 1 & 16.4 & 17.5 & 13.3 & 14.3 & 13.9 \\
\hline 5. & 18.7 & 19.4 & 15.1 & 16.5 & 16.2 \\
\hline
\end{tabular}

Exports from the U.S.

1. \% of Wor 1d Exports

2. $\%$ of Developed-Country Exports

Exports by U.S. Firms inc1. Majority-Owned

\section{Affiliates}

3. \% of Wor 1d Exports

4. $\%$ of Developed-Country Exports

Exports by U.S. Firms, inc 1. Al1 Affiliates

5. \% of World Exports

6. $\%$ of Developed-Country Exports

23.9

25.2

NA

26.

23.0

24.3

20.9

$21.4 \quad 21.5$

30.9

25.8

26.3

22.9

$23.5 \quad 23.8$

Exports by U.S. Multinational Enterprises

inc l. Majority-Owned Affiliates

7. \% of World Exports

8. \% of Developed-Country Exports

$\begin{array}{llllll}\text { NA } & 17.4 & 17.7 & 17.6 & 17.7 & 17.7\end{array}$

$\begin{array}{llllll}\text { NA } & 19.4 & 19.1 & 19.1 & 19.3 & 19.4\end{array}$

Exports by U.S. Multinational Enterprises, incl. All Affiliates

9. \% of World Exports

10. \% of Developed-Country Exports

NA

17.8

$\begin{array}{llll}\text { NA } & 19.8 & 19.4 & 20.1\end{array}$

18.1

18.8

Exports by U.S. Multinationals (Parents) from the U.S.

11. \% of Wor 1d Exports

12. * of Developed-Country Exports

NA

NA

10.8

12.3

11.0

NA

12.1

62.7

9.2

10.5

69.4

$9.5 \quad 9.1$

$10.9 \quad 10.6$

66.265 .2

Exports by U.S. Majority-Owned Affiliates

14. \% of World Exports other than U.S.

5.8

7.9

8.2

9. 7

10.2

$9.7 \quad 10.0$

6.6

8.7

8.7

6.5
47.7

$10.0 \quad 10.5$

16. \% of Developing-Country Exports

2.8

3.6

4.8

$7.7 \quad 7.4$

17. $\%$ of U.S. Multinational Enterprise Exports

18. * of U.S. Firms' Exports
NA

38.1

$\begin{array}{lll}17.6 & 28.9 & 27.8\end{array}$

40.0

$46.7 \quad 48.7$

$38.7 \quad 40.2$ 
Appendix Table U-1 (concluded)

\begin{tabular}{|c|c|c|c|c|c|}
\hline & & & & & \\
\hline & Compar & able to & & & \\
\hline 1957 & 1957 & $\begin{array}{l}\text { Later } \\
\text { Years }\end{array}$ & 1977 & 1982 & 1983 \\
\hline & & & & 1902 & 1983 \\
\hline
\end{tabular}

Exports by Al1 U.S. Affiliates

19. \% of Wor1d Exports other than U.S. $\quad$ NA $9.0 \quad 9.3 \quad 11.4$

20. \% of Developed-Country Exp. except U.S. $\quad$ NA $\quad 9.9 \quad 9.8 \quad 11.8$

21. \% of Developing-Country Exports

22. \% of U.S. Multinational Enterprise Exports

NA $\quad 4.2 \quad 5.6 \quad 8.9$

23. \% of U.S. Firms' Exports

NA $\quad 42.4 \quad 42.4 \quad 52.4$

NA $\quad 31.5 \quad 30.5 \quad 44.0$

Notes to Appendix Table U-1

All Data are from Appendix Table $U-1 a$, except as indicated.

Line 1: Line $3 \div$ Line 1 for 1957 and comparable 1966; for other years, Tables U-3 and U-6 2: Line $3 \div$ Line 2 for 1957 and comparable 1966; for other years, Tables U-3 and U-6

3: Line $19 \div$ Line 1

4: Line $20 \div$ Line 2

5: Line $21 \div$ Line 1

6: Line $22 \div$ Line 2

7: Line $15 \div$ Line 1

8: Line $16 \div$ Line 2

9: Line $17 \div$ Line 1

10: Line $18 \div$ Line 2

11: Line $8 \div$ Line 1

12: Line $8 \div$ Line 2

13: Line $8 \div$ Line 3

14: Line $9 \div$ (Line 1 minus Line 3 )

15: Line $10 \div$ Line 4

16: Line $11 \div$ Line 5

17: Line $9 \div$ Line 15

18: Line $9 \div$ Line 19

19: (Line 9 plus Line 12) $\div$ (Line 1 minus Line 3 )

20: (Line 10 plus Line 13) $\div$ Line 4

21: (Line 11 plus Line 14) $\div$ Line 5

22: (Line 9 plus Line 12) $\div$ Line 17

23: (Line 9 plus Line 12) $\div$ Line 21 


\section{Appendix Table U-1a \\ Estimates of World (Market Economy) Exports of Manufactures and of Exports by U.S. Multinationals \\ $1957,1966,1977,1982$, and 1983 \\ (Unit: \$ billion)}

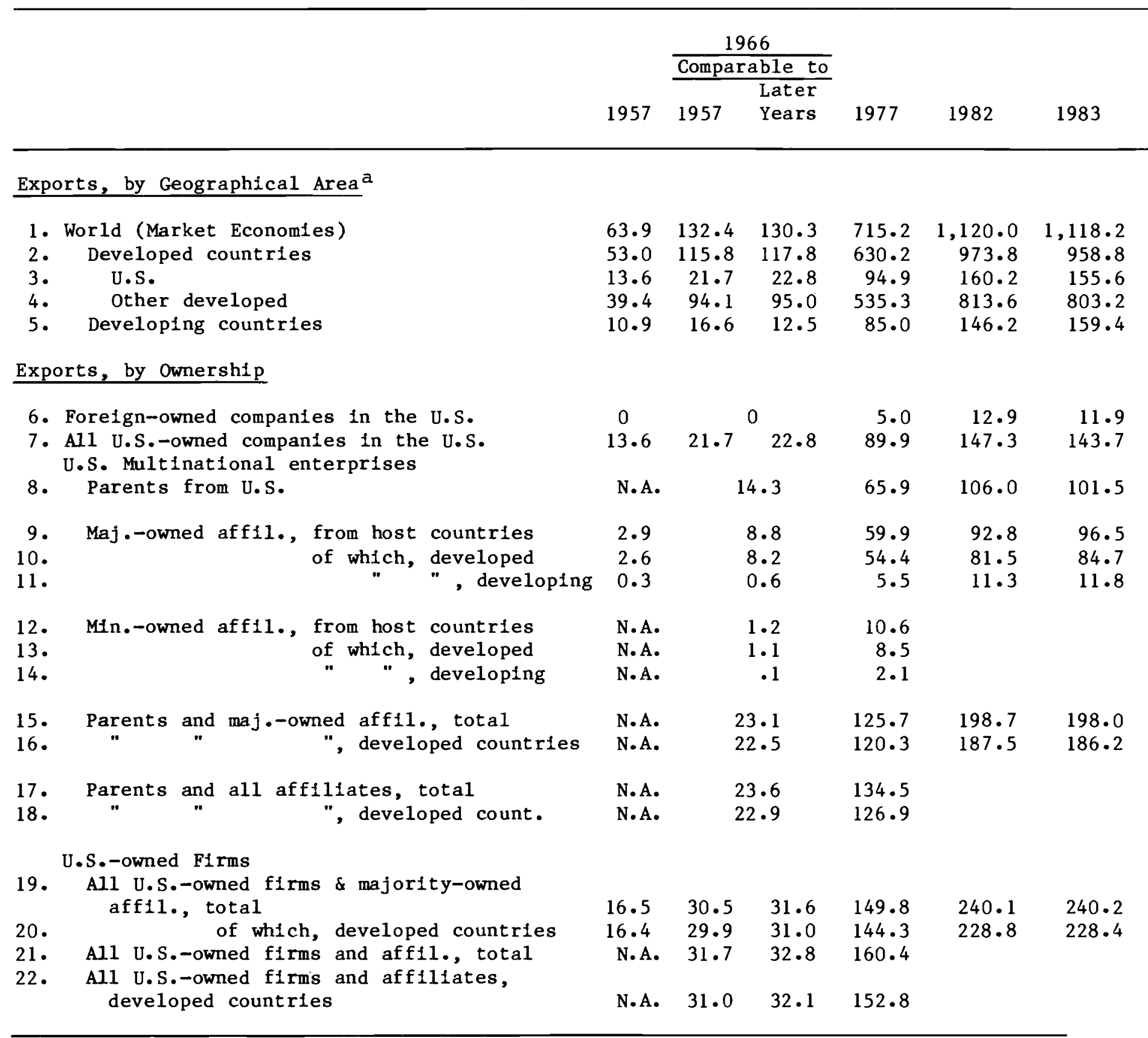


Notes to Appendix Table U-1a

${ }^{a}$ For 1975 and 1966 comparable to 1957, SITC 0, 1, 4-8, less 041-045. These totals include substantial amounts of non-manufactured products but were the best approximations that could be made for these two years. For other years the definition of manufactured products follows that used in the BEA direct investment surveys. That definition is itself adapted from the U.S. Census Bureau's ESIC. One important difference is that petroleum refining is not included in manufacturing but is placed in a separate petroleum industry that we do not include here.

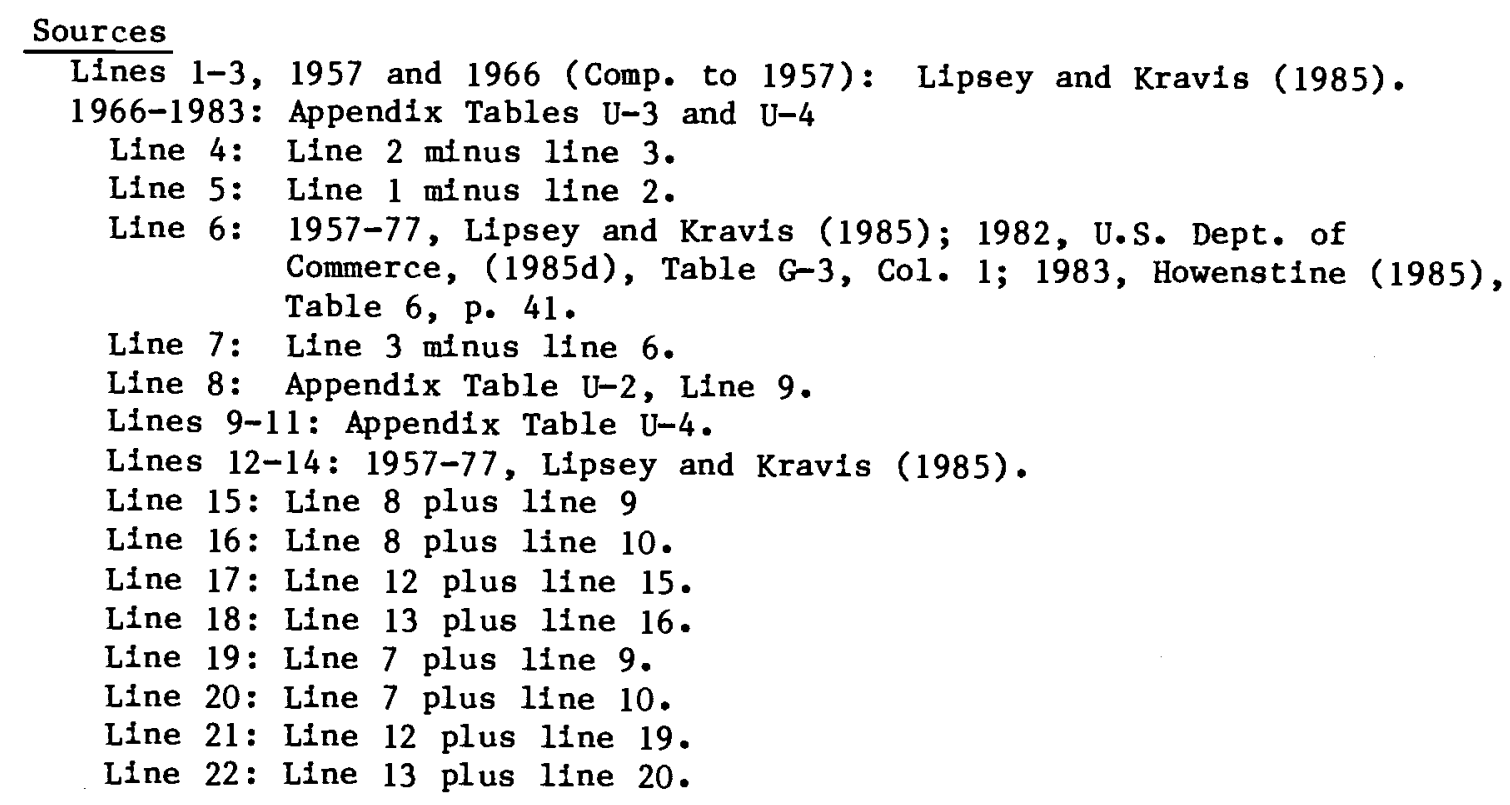


Appendix Table $U-1 b$

Shares of the U.S. In Market Economy, and DME Manufactured Exports Annual Data, 1955-1984

\begin{tabular}{|c|c|c|c|c|c|c|c|c|c|}
\hline & \multicolumn{5}{|c|}{ U.S Exports (s million) } & \multicolumn{4}{|c|}{ U.S. as \% of } \\
\hline & $\begin{array}{l}\text { Total } \\
\text { Exports } \\
\text { SITC } \\
0-9 \\
(1)\end{array}$ & $\begin{array}{c}\text { Chemicals } \\
\text { SITC } \\
5 \\
(2)\end{array}$ & $\begin{array}{l}\text { Machinery } \\
\text { \& Transport } \\
\text { Equipment } \\
\text { SITC } \\
7 \\
\text { (3) }\end{array}$ & $\begin{array}{l}\text { Other } \\
\text { Mfd. } \\
\text { Goods } \\
\text { SITC } \\
6+8 \\
(4)\end{array}$ & $\begin{array}{l}\text { Total } \\
\text { Manufactures } \\
\text { SITC } \\
5-8 \\
\text { (5) }\end{array}$ & $\begin{array}{l}\text { SITC } \\
0-9 \\
(6)\end{array}$ & $\begin{array}{r}\text { SITC } \\
5-8 \\
(7)\end{array}$ & $\begin{array}{c}\text { Devel. Market } \\
\text { SITC } \\
0-9 \\
\text { (8) }\end{array}$ & $\begin{array}{r}\text { Econ. } \\
\text { SITC } \\
5-8 \\
(9)\end{array}$ \\
\hline $\begin{array}{l}1984^{a} \\
1983^{a} \\
1982^{a} \\
1981^{a} \\
1980^{a} \\
1980^{b} \\
1979^{b} \\
1978^{b} \\
1977^{b} \\
1976^{b} \\
1975^{b} \\
1974^{c} \\
1973^{c} \\
1972 \\
1971 \mathrm{~b} \\
1970^{b} \\
1969^{5} \\
1968 \\
1967 \\
1966 \\
1965 \\
1964 \\
1963 \\
1962 \\
1961 \\
1960 \\
1959 \\
1958 \\
1957 \\
1956 \\
1955\end{array}$ & $\begin{array}{l}212,057 \\
195,969 \\
207,160 \\
228,888 \\
216,592 \\
212,887 \\
173,645 \\
139,999 \\
117,926 \\
113,323 \\
106,157 \\
97,144 \\
70,246 \mathrm{~d} \\
48,979 \mathrm{e} \\
43,492 \\
42,590 \\
37,460 \mathrm{~g} \\
33,950^{\mathrm{g}} \\
31,150_{\mathrm{g}} \\
29,900^{\mathrm{g}} \\
27,003_{\mathrm{g}} \\
26,280_{\mathrm{k}} \\
22,920_{\mathrm{k}}^{\mathrm{g}} \\
21,450_{\mathrm{k}} \\
20,790_{\mathrm{k}} \\
20,410_{\mathrm{k}} \\
17,470_{\mathrm{k}} \\
17,760 \mathrm{k} \\
20,690 \mathrm{1} \\
18,950 \mathrm{1} \\
15,430 \mathrm{1}\end{array}$ & $\begin{array}{c}22,388 \\
19,748 \\
19,906 \\
21,148 \\
20,728 \\
22,778 \\
18,665 \\
13,612 \\
10,816 \\
9,958 \\
8,705 \\
8,819 \\
5,749 \\
4,133 \mathrm{c} \\
3,836 \\
3,826 \\
3,380 \\
3,290^{b} \\
2,800^{j} \\
2,680^{j} \\
2,402\end{array}$ & $\begin{array}{l}89,855 \\
82,417 \\
86,954 \\
95,529 \\
84,512 \\
85,637 \\
71,507 \\
60,156 \\
51,027 \\
49,510 \\
45,710 \\
38,188 \\
27,869 \\
21,533^{c} \\
19,460^{d} \\
17,882 \\
16,400 \\
14,450^{b} \\
12,570_{j}^{j} \\
11,160^{j} \\
10,016\end{array}$ & $\begin{array}{c}31,080 \\
30,412 \\
33,017 \\
37,724 \\
38,854 \\
36,320 \\
26,933 \\
21,136 \\
18,649 \\
17,828 \\
16,609 \\
16,532 \\
11,121 \\
8,103^{\mathrm{c}} \\
7,159^{\mathrm{d}} \\
7,662 \\
7,020 \\
5,900^{\mathrm{h}} \\
5,390^{\mathrm{i}} \\
5,320^{\mathrm{j}} \\
4,870\end{array}$ & $\begin{array}{r}143,323 \\
132,577 \\
139,877 \\
154,401 \\
144,094 \\
144,735 \\
117,105 \\
94,904 \\
80,492 \\
77,296 \\
71,024 \\
63,539 \\
44,739 \\
33,769 \\
30,455 \\
29,370 \\
26,800 \\
23,640 \\
20,760 \\
19,160 \\
17,288\end{array}$ & $\begin{array}{l}11.1 \\
10.8 \\
11.2 \\
11.6 \\
10.8 \\
10.7 \\
10.6 \\
10.8 \\
10.5 \\
11.5 \\
12.2 \\
11.6 \\
12.3 \\
11.9 \\
12.5 \\
13.7 \\
13.8 \\
14.3 \\
14.6 \\
14.8 \\
14.1 \\
15.3 \\
14.9 \\
15.2 \\
15.5 \\
16.0 \\
15.1 \\
16.5 \\
18.5 \\
18.3 \\
16.5\end{array}$ & $\begin{array}{l}12.3 \\
12.2 \\
13.0 \\
13.8 \\
12.7 \\
12.7 \\
12.0 \\
11.7 \\
12.0 \\
13.2 \\
13.7 \\
13.1 \\
12.3 \\
12.5 \\
13.4 \\
14.5 \\
15.2 \\
15.8 \\
15.9 \\
15.8 \\
15.7\end{array}$ & $\begin{array}{l}17.2 \\
16.9 \\
17.6 \\
18.4 \\
17.1 \\
16.9 \\
16.2 \\
16.1 \\
16.2 \\
17.6 \\
18.4 \\
17.9 \\
17.3 \\
16.5 \\
17.3 \\
19.0 \\
19.4 \\
20.3 \\
20.9 \\
21.2 \\
21.1 \\
22.4 \\
22.1 \\
22.6 \\
23.0 \\
23.9 \\
23.2 \\
25.0 \\
27.6 \\
27.6 \\
25.5\end{array}$ & $\begin{array}{l}15.6 \\
15.5 \\
16.2 \\
17.0 \\
15.4 \\
15.4 \\
14.5 \\
14.1 \\
14.5 \\
15.9 \\
16.4 \\
15.7 \\
14.8 \\
14.9 \\
16.0 \\
17.4 \\
18.1 \\
18.9 \\
19.1 \\
18.9 \\
19.2\end{array}$ \\
\hline
\end{tabular}




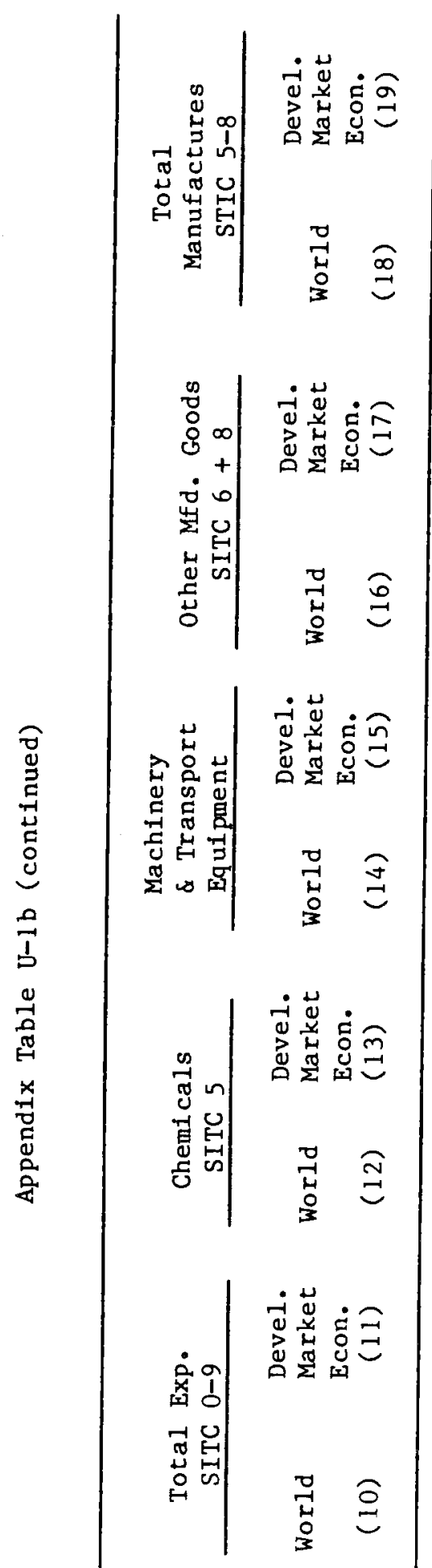

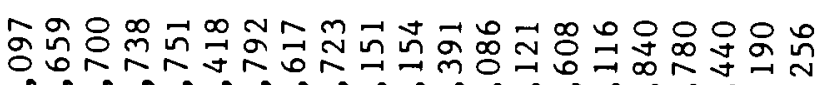
ดी

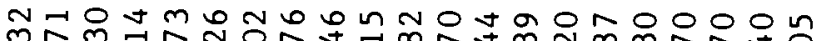
の̄

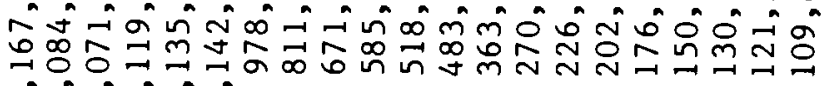

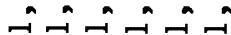

Non

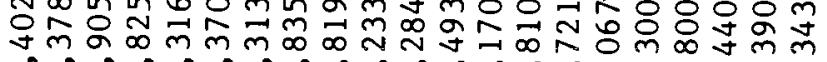

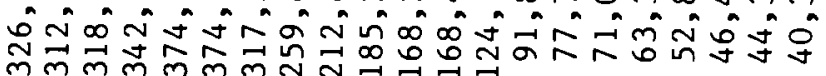

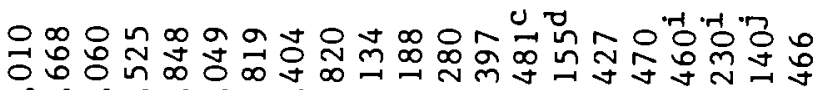

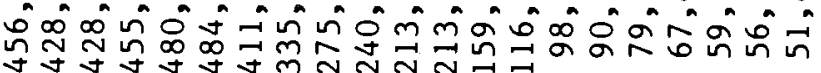

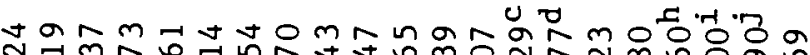

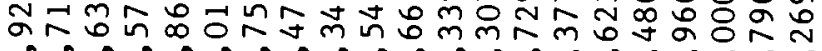

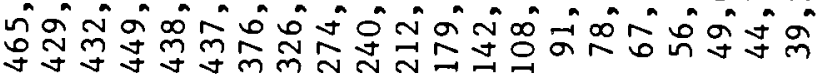

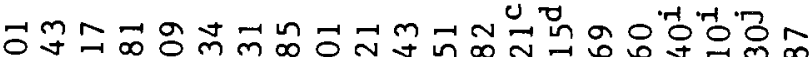

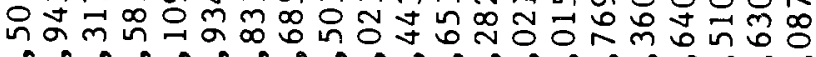

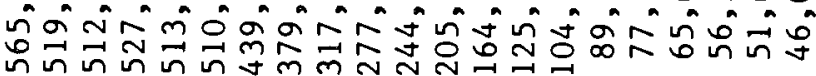

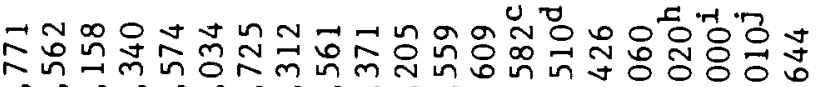

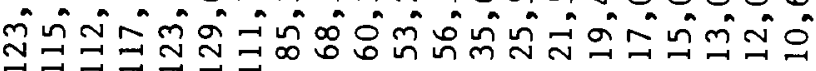

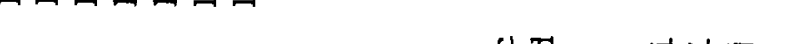

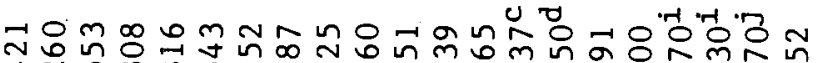
$\checkmark N$ n

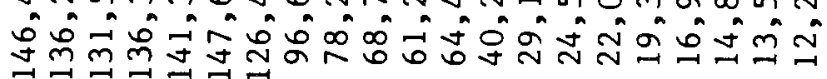

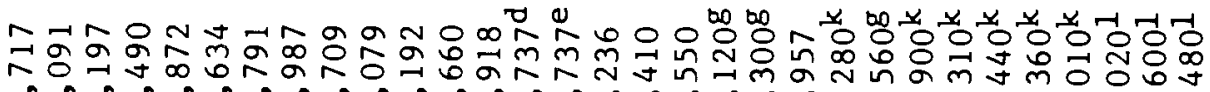

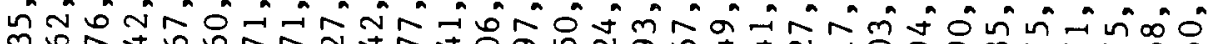

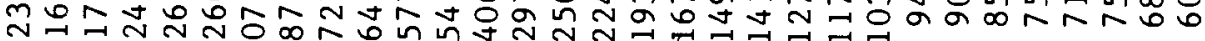

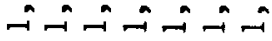

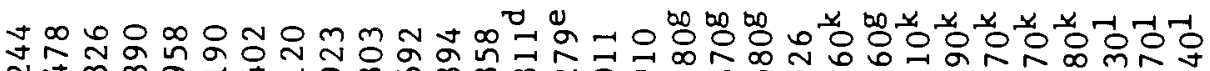
సิษ त̂mळ

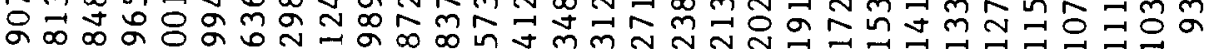

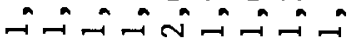

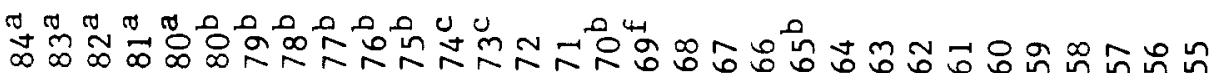
。 
Notes to Appendix Table U-1b

${ }^{a}$ UN, Monthly Bullet1n of Statistics, Feb. 1986, Special Table D (Rev. 2)

$\mathrm{b}_{\mathrm{UN}}$, International Trade Statistics Yearbook, 1983, Vol. I, Specia1 Table B

$\mathrm{c}_{\mathrm{UN}}$, Internationa1 Trade Stat1st1cs Yearbook, 1981, Vol. I, Spectal Table C (Rev. 1)

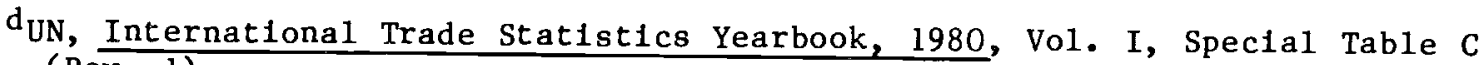
(Rev. 1) eUN, International Trade Statist1cs Yearbook, 1976, Vol. I, Special Table B2
(Rev. 1)

$\mathrm{f}_{\mathrm{UN}}$ (Rev. Internat1ona1 Trade Stat1st1cs Yearbook, 1974, Vol. I, Spec1a1 Table B

gUN, International Trade Stat1st1cs Yearbook, 1972-73, Table B (Rev. 1)

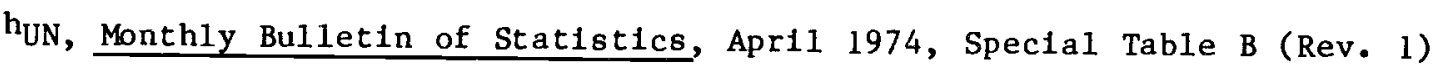

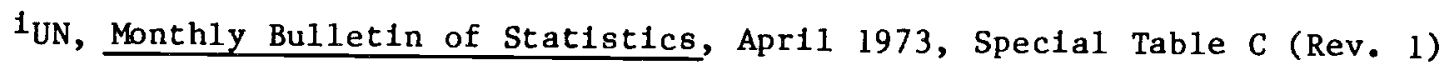

JUN, Monthly Bulletin of Statistics, April 1972, Special Table C (Rev. 1)

$\mathrm{k}_{\mathrm{UN}}$, Internationa1 Trade Statistics Yearbook, 1969, Table B

$1_{U N}$ International Trade Statistics Yearbook, 1966, Table B.

Columns 6-9 are columns 1 and 5 divided by columns 10, 11, 18, and 19. 
Appendix Table $U-2$

Estimate of U.S. Manufacturing Parent Exports of All Products and of Their Own Products $1966,1977,1982$, and 1983 (Unit: \$million)

By U.S. parents to

\begin{tabular}{r} 
Repor \\
\hline $\begin{array}{l}\text { Affil } \\
\text { iates }\end{array}$ \\
5,343 \\
4,958
\end{tabular}
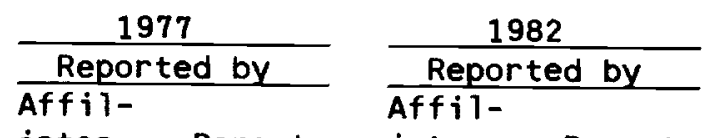

$\frac{1983}{\text { Reported by }}$
$\begin{aligned} & \text { Affi1- } \\ & \text { iates Parents }\end{aligned}$

Maj.-owned affil.

1. all prod.

4,958

25,769

24,330

38,262

38,992

37,003

40,120

40,728

23,089

38,651

Other affil.

3. all prod.

4. own prod.

$$
2,492 \quad 2,353
$$

2,233

1,830

1,865

1,770

2,131

2,077

1,971

All affil.

5. al1 prod.

6. Own prod.

5,974

5,544

28,260

26,683

25,322

40,092

40,857

38,773

42,251

42,891

40,622

Unaff. foreigners

7. all prod.

8. own prod.

8,356

7,960

39,194

38,163

65,110

63,397

58,581

57,040

A11 aff. and unaff. foreigners

9. al1 prod.

10. own prod.

14,330

65,877

63,485

105,967

102,170

101,472

97,662 
Sources to Appendix Table U-2:

Line 1, 1966: U.S. Department of Commerce (1975), Table E-1, p. 82

1977: Reported by affiliates: U.S. Department of Commerce (1981), Table II. T1, p. 185 .

1982: Reported by Affiliates, U.S. Dept. of Commerce (1985), Table II.P1, Col. 6 .

1977 and 1982: Reported by parents: Line 5 multiplied by the ratio of Line 1 to Line 5 for data reported by affiliates.

Line 2, 1966: U.S. Department of Commerce (1975), Table E-1, p. 82.

1977 and 1982: Line 1 multiplied by the estimated ratio of exports of own products to exports of all products. Ratio is estimated as .949. It is derived from .9741 (Line 8/Line 7) multiplied by $.928 / .953$, the 1966 ratio of Line $2 /$ Line 1.

Line 3, 1977, Reported by affiliates: U.S. Dept. of Commerce (1981), Table II.T1

Reported by parents: Line 5 minus Line 1 .

1982, Reported by affiliates: U.S. Dept. of Commerce (1985), Table II.P1, Col. 9.

Reported by parents: Line 5 minus Line 1 .

Line 4, 1977 and 1982: Line 3 multiplied by the ratio used for line 2.

Line 5, 1966: Table U-3a, Col. 8.

1977, Reported by affiliates: U.S. Department of Commerce (1981), Table II, T1, p. 185, Col. 3.

Reported by parents: U.S. Department of Commerce (1981), Table II. T1, p. 185, Col. 13.

1982, Reported by affiliates: U.S. Dept. of Commerce (1985), Table II.P1, Col. 3 .

Reported by parents: U.S. Dept. of Commerce (1985), Table II.P1, Col. 13 .

Line 6, 1966: Line 2 multiplied by the ratio of line 5 to line 1 . 1977 and 1982: Line 2 plus Line 4.

Line 7, 1966: U.S. Department of Commerce (1975), Table E-1, p. 82. 1977: U.S. Department of Commerce (1981), Table II.T1, p. 185, Col. 11 .

1982: U.S. Department of Commerce (1985), Table II.P1, Col. 11.

Line 8, 1966: U.S. Department of Commerce (1975), Table E-1, p. 82.

1977: Line 7 multiplied by the ratio for exports to unaffiliated foreigners of exports of own products to exports of all products (.9737) from U.S. Department of Commerce (1981), Table II. T3, p. 187, Col. $12 \& 13$.

1978: Line 7 multiplied by the same ratio as for 1977 .

Line 9: Line 5 plus Line 7.

Line 10: Line 6 plus line 8. 
Appendix Table U-3

Exports from the U.S. by U.S. Multinationals (Parent Firms) and by All Firms, By Industry Group, 1966, 1977, 1982, and 1983

(Unit: \$ million)

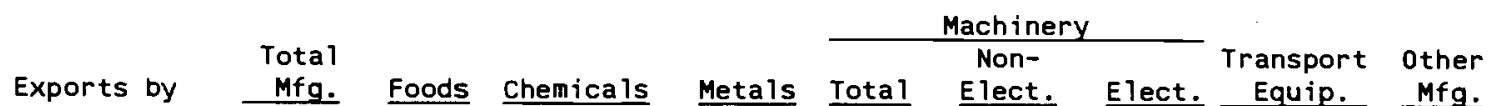

1966

$\begin{array}{rrrrrrrrrrr}1 . & 22,827 & 1,985 & 2,909 & 2,717 & 6,559 & 4,759 & 1,800 & 4,480 & 4,177 \\ \text { 2. } & 14,330 & 663 & 2,041 & 1,306 & 4,348 & \text { NA } & \text { NA } & 3,743 & 2,230 \\ \text { 3. } & 8,497 & 1,322 & 868 & 1,411 & 2,211 & \text { NA } & \text { NA } & 737 & 1,947 \\ & & & & & & & & \end{array}$

\begin{tabular}{rrrrrrrrrrr}
\hline & & & & & & \\
1. & 94,890 & 7,194 & 11,421 & 7,115 & 29,291 & 19,857 & 9,434 & 22,466 & 17,403 \\
2. & 65,877 & 2,683 & 9,130 & 4,271 & 20,147 & 12,446 & 7,701 & 19,640 & 10,005 \\
3. & 29,013 & 4,511 & 2,291 & 2,844 & 9,144 & 7,411 & 1,733 & 2,826 & 7,398 \\
4. & 3,557 & 327 & 987 & 429 & 1,095 & 700 & 395 & 25 & 695 \\
5. & 25,456 & 4,184 & 1,304 & 2,415 & 8,049 & 6,711 & 1,338 & 2,801 & 6,703
\end{tabular}

1982

\begin{tabular}{|c|c|c|c|c|c|c|c|c|c|}
\hline 1. & 160,169 & 10,692 & 21,389 & 12,715 & 54,392 & 37,180 & 17.212 & 31.676 & 29305 \\
\hline 2. & 105,967 & 3,884 & 16,065 & 7,119 & 35,612 & 19,378 & 16,234 & 28,438 & 14,849 \\
\hline 3. & 54,202 & 6,808 & 5,324 & 5,596 & 18,780 & 17,802 & 978 & 3,238 & 14,456 \\
\hline 4. & 12,883 & 597 & 4,722 & 1,153 & 3,459 & 1,905 & 1,554 & 1,441 & 1,510 \\
\hline 5. & 41,319 & 6,211 & 602 & 4,443 & 15,321 & 15,897 & -576 & 1,797 & 12,946 \\
\hline & & & & & 83 & & & & \\
\hline 1. & 155,568 & 11,070 & 20,985 & 11,148 & 50,023 & 32,375 & 17,648 & 32,452 & 29,890 \\
\hline 2. & 101,472 & 4,950 & 15,184 & 4,977 & 33,204 & 16,725 & 16,479 & 29,253 & 13,905 \\
\hline 3. & 54,096 & 6,120 & 5,801 & 6,171 & 16,819 & 15,650 & 1,169 & 3,199 & 15,985 \\
\hline 4. & 11,910 & 542 & 4,601 & 1,189 & 3,234 & 1,696 & 1,538 & 1,011 & 1,333 \\
\hline 5. & 42,186 & 5,578 & 1,200 & 4,982 & 13,585 & 13,954 & -369 & 2,188 & 14,652 \\
\hline
\end{tabular}

Exporter

definitions:

1. U.S.

2. Parent firms

3. Dther firms in U.S.

4. Foreign-owned firms

5. Non-multinational U.S. firms

Sources: U.S. Exports: For 1966-1982, data from United Nations trade tapes at the 4-digit SITC level converted to industry data by a concordance at that level and combined with estimates in Appendix Table U-14. For 1983, extrapolated from 1982 using data at the 1-digit and, to some extent, 2-digit levels from various issues of the UN Monthly Bulletin of Statistics

Parent Firm Exports, by Industry of Parents

1966: Appendix Table U-3a

1977: U.S. Department of Commerce (1982), Table II.T 1, Col. 11, plus Col. 13

1982: U.S. Department of Commerce (1985a), Table II.P 1, Col. 11 plus Col. 13

1983: U.S. Department of Commerce (1985b), Table 57

Foreign-Dwned Firm Exports, by Industry of Affiliate

1977: U.S. Department of Commerce (1985c), Table G-3, Co1. 1, p. 164

1982: U.S. Department of Commerce (1985d), Table G-3, Col. 1

1983: U.S. Department of Commerce (1985e), Table G-3, Co 1. 1 


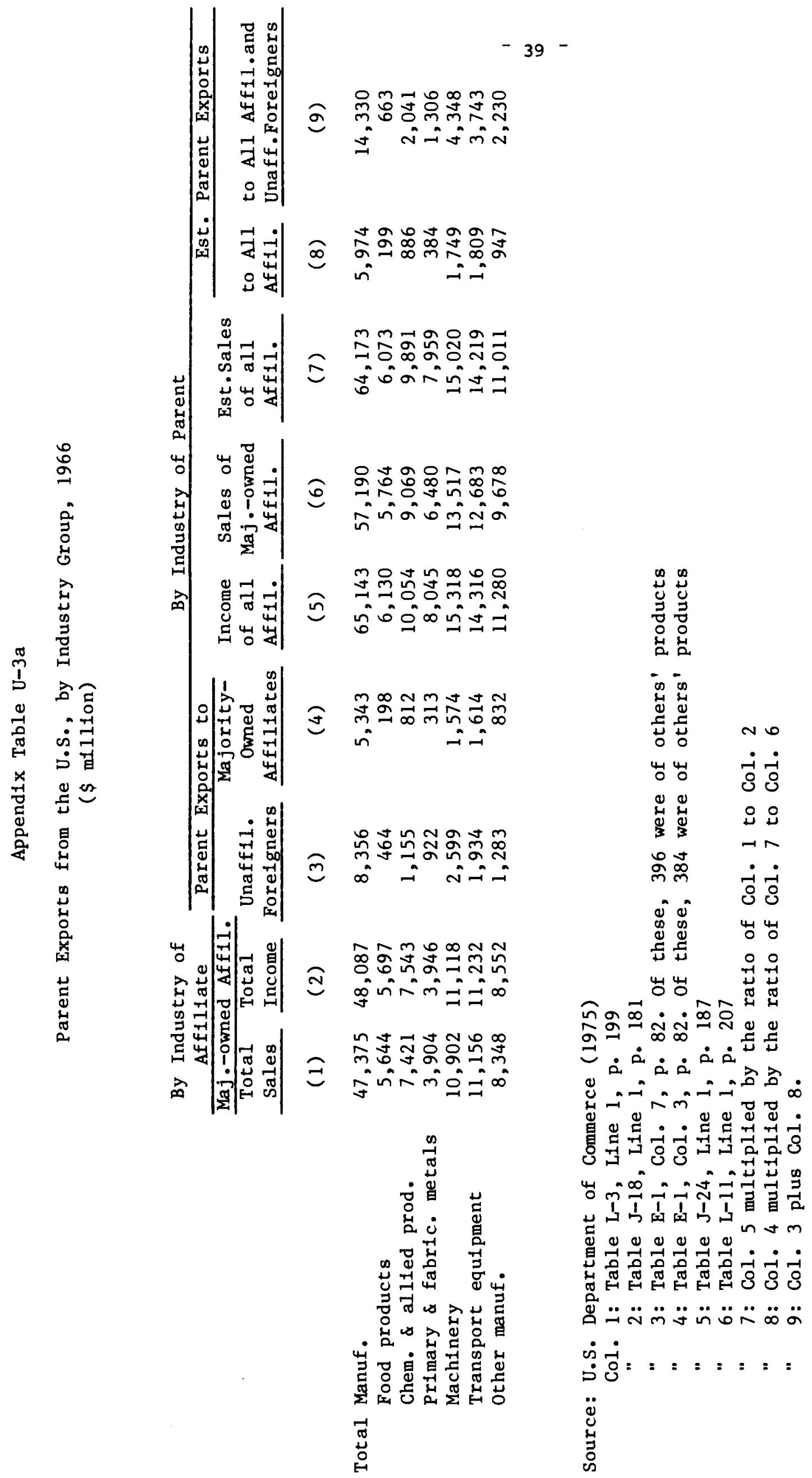


Exports of Majority-Owned Manufacturing Affiliates, by Industry Group of Affiliate and Destination (Unit: \$million)






\begin{tabular}{|c|c|c|c|c|c|c|c|c|}
\hline \multirow[b]{2}{*}{ Destination } & \multirow[b]{2}{*}{ Total } & \multirow[b]{2}{*}{ Foods } & \multirow[b]{2}{*}{ Chemicals } & \multirow[b]{2}{*}{ Metals } & \multicolumn{2}{|c|}{ Machinery } & \multirow[b]{2}{*}{$\begin{array}{l}\text { Transport } \\
\text { Equ1 pment }\end{array}$} & \multirow[b]{2}{*}{$\begin{array}{l}\text { Other } \\
\text { Mfg. }\end{array}$} \\
\hline & & & & & $\begin{array}{l}\text { Non- } \\
\text { Elect. }\end{array}$ & Elect. & & \\
\hline & \multicolumn{8}{|c|}{1982 (Unadjusted) } \\
\hline $\begin{array}{l}\text { To U.S. } \\
\text { from Developed Countries } \\
\text { from LDCs }\end{array}$ & $\begin{array}{r}26,244 \\
20,099 \\
6,144\end{array}$ & $\begin{array}{l}570 \\
431 \\
139\end{array}$ & $\begin{array}{r}2,043 \\
1,598 \\
445\end{array}$ & $\begin{array}{l}740 \\
500 \\
239\end{array}$ & $\begin{array}{r}3,073 \\
2,601 \\
471\end{array}$ & $\begin{array}{r}4,630 \\
780 \\
3,850\end{array}$ & $\begin{array}{r}12,190 \\
11,693 \\
587\end{array}$ & $\begin{array}{r}2,998 \\
2,585 \\
413\end{array}$ \\
\hline $\begin{array}{l}\text { To other Countries } \\
\text { from Developed Countries } \\
\text { from LDCs }\end{array}$ & $\begin{array}{r}65,588 \\
60,564 \\
5,024\end{array}$ & $\begin{array}{r}4,524 \\
3,806 \\
718\end{array}$ & $\begin{array}{r}15,341 \\
14,490 \\
851\end{array}$ & $\begin{array}{r}3,121 \\
2,764 \\
357\end{array}$ & $\begin{array}{r}13,347 \\
12,596 \\
751\end{array}$ & $\begin{array}{l}5,646 \\
4,362 \\
1,285\end{array}$ & $\begin{array}{r}12,558 \\
12,240 \\
318\end{array}$ & $\begin{array}{r}11,052 \\
10,306 \\
745\end{array}$ \\
\hline $\begin{array}{l}\text { To All Countries } \\
\text { from Developed Countries } \\
\text { from LDCs }\end{array}$ & $\begin{array}{l}91,832^{b} \\
80,663 \\
11,168\end{array}$ & $\begin{array}{r}5,094 \\
4,237 \\
857\end{array}$ & $\begin{array}{r}17,383 \\
16,088 \\
1,296\end{array}$ & $\begin{array}{r}3,861 \\
3,264 \\
596\end{array}$ & $\begin{array}{r}16,419 \\
15,197 \\
1,222\end{array}$ & $\begin{array}{r}10,277 \\
5,142 \\
5,135\end{array}$ & $\begin{array}{r}24,739 \\
23,933 \\
905\end{array}$ & $\begin{array}{r}14,050 \\
12,891 \\
1,158\end{array}$ \\
\hline $\begin{array}{l}\text { To U.S. } \\
\text { from Developed Countries } \\
\text { from LDCs }\end{array}$ & $\begin{array}{r}26,511 \\
20,303 \\
6,206\end{array}$ & $\begin{array}{l}576 \\
435 \\
140\end{array}$ & $\begin{array}{r}2,064 \\
1,614 \\
450\end{array}$ & $\begin{array}{l}1982(\text { Ad } \\
748 \\
505 \\
241\end{array}$ & $\begin{array}{r}\text { justed } \mathrm{f} \\
3,104 \\
2,627 \\
476\end{array}$ & $\begin{array}{c}\text { or Covera } \\
4,677 \\
788 \\
3,889\end{array}$ & $\begin{array}{r}12,314 \\
11,812 \\
593\end{array}$ & $\begin{array}{r}3,028 \\
2,611 \\
417\end{array}$ \\
\hline $\begin{array}{l}\text { To Other Countries } \\
\text { from Developed Countries } \\
\text { from LDCs }\end{array}$ & $\begin{array}{r}66,254 \\
61,179 \\
5,057\end{array}$ & $\begin{array}{r}4,570 \\
3,845 \\
725\end{array}$ & $\begin{array}{r}15,497 \\
14,637 \\
860\end{array}$ & $\begin{array}{r}3,153 \\
2,792 \\
361\end{array}$ & $\begin{array}{r}13,483 \\
12,724 \\
759\end{array}$ & $\begin{array}{l}5,703 \\
4,406 \\
1,298\end{array}$ & $\begin{array}{r}12,686 \\
12,364 \\
321\end{array}$ & $\begin{array}{r}11,164 \\
10,411 \\
753\end{array}$ \\
\hline $\begin{array}{l}\text { To All Countrles } \\
\text { fron Developed Countries } \\
\text { from LDCs }\end{array}$ & $\begin{array}{l}92,765 \\
81,482 \\
11,281\end{array}$ & $\begin{array}{r}5,146 \\
4,280 \\
866\end{array}$ & $\begin{array}{r}17,560 \\
16,251 \\
1,309\end{array}$ & $\begin{array}{r}3,900 \\
3,297 \\
602\end{array}$ & $\begin{array}{r}16,586 \\
15,351 \\
1,234\end{array}$ & $\begin{array}{r}10,381 \\
5,194 \\
5,187\end{array}$ & $\begin{array}{r}24,990 \\
24,176 \\
914\end{array}$ & $\begin{array}{r}14,193 \\
13,022 \\
1,170\end{array}$ \\
\hline $\begin{array}{l}\text { To U.S. } \\
\text { from Developed Countries } \\
\text { from LDCs }\end{array}$ & $\begin{array}{r}31,540 \\
24,338 \\
7,202\end{array}$ & $\begin{array}{l}480 \\
339 \\
142\end{array}$ & $\begin{array}{r}2,168 \\
1,808 \\
360\end{array}$ & $\begin{array}{l}1983 \\
750 \\
649 \\
101\end{array}$ & $\begin{array}{l}\text { (Unadju } \\
3,778 \\
2,671 \\
1,107\end{array}$ & $\begin{array}{r}\text { sted) } \\
5,117 \\
930 \\
4,187\end{array}$ & $\begin{array}{r}15,920 \\
15,098 \\
822\end{array}$ & $\begin{array}{r}3,328 \\
2,844 \\
484\end{array}$ \\
\hline $\begin{array}{l}\text { To Other Countries } \\
\text { from Developed Countries } \\
\text { from LDCs }\end{array}$ & $\begin{array}{r}63,995 \\
59,513 \\
4,482\end{array}$ & $\begin{array}{r}4,230 \\
3,594 \\
636\end{array}$ & $\begin{array}{r}15,634 \\
14,886 \\
748\end{array}$ & $\begin{array}{r}2,851 \\
2,589 \\
262\end{array}$ & $\begin{array}{r}13,758 \\
13,154 \\
604\end{array}$ & $\begin{array}{l}5,228 \\
3,980 \\
1,249\end{array}$ & $\begin{array}{r}11,957 \\
11,691 \\
266\end{array}$ & $\begin{array}{r}10,337 \\
9,620 \\
717\end{array}$ \\
\hline $\begin{array}{l}\text { To All Countries } \\
\text { from Developed Countries } \\
\text { from LDCs }\end{array}$ & $\begin{array}{l}95,535 \\
83,851 \\
11,684\end{array}$ & $\begin{array}{r}4,709 \\
3,933 \\
778\end{array}$ & $\begin{array}{r}17,802 \\
16,694 \\
1,108\end{array}$ & $\begin{array}{r}3,601 \\
3,238 \\
363 \\
1983(\mathrm{Ad} \\
\end{array}$ & $\begin{array}{r}17,537 \\
15,825 \\
1,711 \\
\text { justed } \mathbf{f} \\
\end{array}$ & $\begin{array}{r}10,345 \\
4,910 \\
5,436 \\
\text { or Covera } \\
\end{array}$ & $\begin{array}{r}27,877 \\
26,789 \\
1,088 \\
\end{array}$ & $\begin{array}{r}13,666 \\
12,464 \\
1,201\end{array}$ \\
\hline $\begin{array}{l}\text { To U.S. } \\
\text { from Developed Countries } \\
\text { from LDCs }\end{array}$ & $\begin{array}{r}31,860 \\
24,585 \\
7,275\end{array}$ & $\begin{array}{l}485 \\
342 \\
143\end{array}$ & $\begin{array}{r}2,190 \\
1,826 \\
364\end{array}$ & $\begin{array}{l}758 \\
656 \\
102\end{array}$ & $\begin{array}{l}3,816 \\
2,698 \\
1,118\end{array}$ & $\begin{array}{r}5,169 \\
939 \\
4,230\end{array}$ & $\begin{array}{r}16,082 \\
15,251 \\
830\end{array}$ & $\begin{array}{r}3,362 \\
2,873 \\
489\end{array}$ \\
\hline $\begin{array}{l}\text { To Other Countries } \\
\text { from Developed Countries } \\
\text { from LDCs }\end{array}$ & $\begin{array}{r}64,645 \\
60,117 \\
4,528\end{array}$ & $\begin{array}{r}4,273 \\
3,630 \\
642\end{array}$ & $\begin{array}{r}15,793 \\
15,037 \\
756\end{array}$ & $\begin{array}{r}2,880 \\
2,615 \\
265\end{array}$ & $\begin{array}{r}13,898 \\
13,288 \\
610\end{array}$ & $\begin{array}{l}5,281 \\
4,020 \\
1,262\end{array}$ & $\begin{array}{r}12,078 \\
11,810 \\
269\end{array}$ & $\begin{array}{r}10,442 \\
9,718 \\
724\end{array}$ \\
\hline $\begin{array}{l}\text { To All Countrles } \\
\text { from Developed Countries } \\
\text { from LDCs }\end{array}$ & $\begin{array}{l}96,505 \\
84,703 \\
11,803\end{array}$ & $\begin{array}{r}4,757 \\
3,973 \\
786\end{array}$ & $\begin{array}{r}17,983 \\
16,864 \\
1,119\end{array}$ & $\begin{array}{r}3,638 \\
3,271 \\
367\end{array}$ & $\begin{array}{r}17,715 \\
15,986 \\
1,728\end{array}$ & $\begin{array}{r}10,450 \\
4,960 \\
5,491\end{array}$ & $\begin{array}{r}28,160 \\
27,061 \\
1,099\end{array}$ & $\begin{array}{r}13,805 \\
12,591 \\
1,213\end{array}$ \\
\hline
\end{tabular}

aSource gives only total machinery $(2,490)$. The breakdown between non-electrical and electrical machinery was estimated assuming that the ratio of exports to income ( 7,016 for nonelectrical machinery and 5,319 for electrical machinery) was identical in the two subgroups. The export ratios in 1977 were $36.1 \%$ for non-electrical machinery and $33.4 \%$ for electrical machinery (U.S. Department of Commerce, 198I, Tables III F.3 and III.H.2. 
Notes to Appendix Table U-4

1957: U.S. Department of Commerce (1960),

By industry, to countries other than U.S., p. 36 .

To U.S., by product, Table 26, Manufactures and semimanufactures plus meat products.

Foods $=$ meat products

Metals = alumi num

Transport equipment $=$ motor vehicles, aircraft, and equipment

Other = Newsprint and pulp; Scientific instruments, Rubber

products, and Other.

To U.S., by industry, total from Table 57 allocated between Canada and Europe using total for all countries from Table 58 and allocated by industry using product distribution and assuming that difference between product and industry total consisted of fabricated metals other than aluminum.

To All Countries, by industry, breakdown between Canada and Europe for all manufacturing from Table 58 and industry breakdown sum of exports to U.S. and exports to other countries.

The share of metals is probably overstated in comparison to data for later years because of the inclusion of publicly-owned companies, $50 \%$ or more owned by U.S. citizens, but with no controlling U.S. interest.

1966: U.S. Department of Commerce (1975), Tables L-1 through L-6.

1977: U.S. Department of Commerce (1981), Tables III.H4 and III.H5. Al1 affiliate export totals from the source multiplied by 1.0016 , the ratio of sales of all nonbank affiliates $(\$ 649,749 \mathrm{mil1.})$ to sales of reporting nonbank affiliates $(\$ 648,708 \mathrm{mil1.})$, from U.S. Dept. of Commerce (1981), Table A, p. 2.

1982: U.S. Department of Commerce (1985a), Tables III.E2, III.E4, and III.E5. All affiliate export totals from the source multiplied by 1.010155 , the ratio of sales of all nonbank affiliates $(\$ 949,213 \mathrm{mil1.})$ to sales of reporting nonbank affiliates $(\$ 939,671$ mili.), from U.S. Dept. of Commerce (1985), Table 1, p. 2.

1983: U.S. Department of Commerce (1985b), Tables 37 and 38, with same adjustment for coverage as for 1982 . 


\section{Appendix Table U-5}

Exports of U.S. Parents and their Majority-Owned Affiliates, by Industry Group and Destination

1966, 1977, 1982, and 1983

(Unit: \$ million)

Total

$\mathrm{Mfg}$
Machinery

$\begin{array}{llll} & \text { Non- } & \text { Transport Other } \\ \text { Total Elect. Elect. } & \text { Equipment Mfg. }\end{array}$

PARENTS AND ALL MAJORITY-OWNED AFFILIATES

$\begin{array}{rrrrrrrrrrr}1966 & 23,147 & 1,329 & 3,066 & 1,694 & 6,838 & \text { NA } & \text { NA } & 6,442 & 3,780 \\ 1977 & 125,746 & 5,917 & 17,591 & 7,370 & 36,929 & 22,925 & 14,004 & 38,541 & 19,418 \\ 1982 & 198,732 & 9,030 & 33,625 & 11,019 & 62,579 & 35,964 & 26,615 & 53,428 & 29,042 \\ 1983 & 197,977 & 9,707 & 33,167 & 8,615 & 61,369 & 34,440 & 26,929 & 57,413 & 27,710 \\ & & & & & & & & & & \\ 1966 & 22,569 & 1,069 & 2,969 & 1,621 & 6,788 & \text { NA } & \text { NA } & 6,434 & 3,685 \\ 1977 & 120,252 & 5,220 & 17,126 & 6,916 & 34,127 & 22,498 & 11,629 & 38,133 & 18,748 \\ 1982 & 187,449 & 8,164 & 32,316 & 10,416 & 56,157 & 34,729 & 21,428 & 52,614 & 27,871 \\ 1983 & 186,175 & 8,923 & 32,048 & 8,248 & 54,150 & 32,711 & 21,439 & 56,584 & 26,496\end{array}$

Source: Appendix Tables U-3 and U-4 
Appendix Table U-6

Exports of Manufactures by All Market Economies and by Developed Market Economies, by Broad Industry Groups,

$1966,1977,1982$, and 1983

(Unit: $\$$ million)

\begin{tabular}{|c|c|c|c|c|c|c|c|c|}
\hline \multirow{3}{*}{$\begin{array}{c}\text { Total } \\
\text { Mfg. }\end{array}$} & \multirow[b]{3}{*}{ Foods } & \multirow[b]{3}{*}{ Chemicals } & \multirow[b]{3}{*}{ Metals } & \multicolumn{3}{|c|}{ Machinery } & \multirow{3}{*}{$\begin{array}{l}\text { Transport } \\
\text { Equipment }\end{array}$} & \multirow{3}{*}{$\begin{array}{c}\text { Other } \\
\text { Mfg. }\end{array}$} \\
\hline & & & & & Non- & & & \\
\hline & & & & Total & Elect. & Elect. & & \\
\hline
\end{tabular}

\begin{tabular}{|c|c|c|c|c|c|c|c|c|c|}
\hline \multicolumn{10}{|c|}{ A11 Market Economies } \\
\hline 1966 & 130,343 & 16,979 & 13,421 & 20,237 & 27,096 & 18,201 & 8,895 & 17,962 & 34,648 \\
\hline 1977 & 715,220 & 79,293 & 76,740 & 93,560 & 162,482 & 98,796 & 63,686 & 122,569 & 180,576 \\
\hline 1982 & $1,119,996$ & 111,074 & 132,365 & 138,937 & 267,347 & 158,752 & 108,595 & 189,643 & 280,630 \\
\hline 1983 & $1,118,196$ & 104,589 & 135,079 & 134,434 & & & $462,412^{a}$ & & 281,682 \\
\hline \multicolumn{10}{|c|}{ Developed Market Economies } \\
\hline 1966 & 117,843 & 11,253 & 13,004 & 17,851 & 26,772 & 18,071 & 8,701 & 17,846 & 31,117 \\
\hline 1977 & 630,216 & 50,809 & 72,578 & 84,057 & 153,849 & 96,587 & 57,262 & 119,666 & 149,257 \\
\hline 1982 & 973,840 & 79,145 & 121,440 & 122,824 & 246,104 & 152,254 & 93,850 & 180,448 & 223,879 \\
\hline 1983 & 958,833 & 74,426 & 125,108 & 111,986 & & & 424,122 & & 223,191 \\
\hline
\end{tabular}

acorresponding total for $1982,457,990$

bcorresponding total for $1982,426,552$

Source: For 1966-1982, data from UN trade tapes, at the 4-digit SITC level converted to industry data by a concordance at that level and combined with estimates in Appendix Table U-14. For 1983, extrapolated from 1982 using data at the 1-digit and, to some extent 2-digit levels from the UN Monthly Bulletin of Statistics. 
Appendix Table U-7

Shares (8) of the U.S. and of U.S. Multinational Firms in Market Economy and Developed Market Economy Exports

\begin{tabular}{|c|c|c|c|c|c|c|c|c|}
\hline \multirow[b]{2}{*}{$\begin{array}{c}\text { Total } \\
\text { Mfg. }\end{array}$} & \multirow[b]{2}{*}{ Foods } & \multirow[b]{2}{*}{ Chemicals } & \multirow[b]{2}{*}{ Metals } & \multicolumn{3}{|c|}{ Machinery } & \multirow[b]{2}{*}{$\begin{array}{l}\text { Transport } \\
\text { Equipment }\end{array}$} & \multirow[b]{2}{*}{$\begin{array}{c}\text { Other } \\
\text { Mfg. }\end{array}$} \\
\hline & & & & Total & $\begin{array}{l}\text { Non- } \\
\text { Elect. }\end{array}$ & Elect. & & \\
\hline
\end{tabular}

SHARE OF ALL MARKET ECONOMIES' EXPORTS

U.S.

\begin{tabular}{|c|c|c|c|c|c|c|c|c|c|}
\hline 1966 & 17.6 & 11.7 & 21.7 & 13.4 & 24.3 & 26.1 & 20.2 & 24.9 & 12.1 \\
\hline 1977 & 13.3 & 9.1 & 14.9 & 7.6 & 18.3 & 20.1 & 14.8 & 18.3 & 9.6 \\
\hline 1982 & 14.3 & 9.6 & 16.2 & 9.2 & 20.3 & 23.4 & 15.8 & 16.7 & 10.4 \\
\hline 1983 & 13.9 & 10.6 & 15.5 & 8.3 & NA & & $17.8^{a}$ & & 10.6 \\
\hline \multicolumn{10}{|c|}{ U.S. Multinational Firms } \\
\hline 1966 & 17.8 & 7.8 & 22.8 & 8.4 & 25.4 & NA & NA & 35.9 & 10.9 \\
\hline 1977 & 17.6 & 7.5 & 22.9 & 7.9 & 23.0 & 23.7 & 22.0 & 31.4 & 10.8 \\
\hline 1982 & 17.7 & 8.1 & 25.4 & 7.9 & 23.4 & 22.7 & 24.5 & 28.2 & 10.3 \\
\hline 1983 & 17.7 & 9.3 & 24.6 & 6.4 & NA & & $25.7^{b}$ & & 9.8 \\
\hline
\end{tabular}

SHARE OF DEVELOPED MARKET ECONOMIES' EXPORTS

U.S.

$\begin{array}{rrrrrrrrrr}1966 & 19.5 & 17.6 & 22.4 & 15.2 & 24.5 & 26.3 & 20.7 & 25.1 & 13.4 \\ 1977 & 15.1 & 14.2 & 15.7 & 8.5 & 19.0 & 20.6 & 16.5 & 18.8 & 11.6 \\ 1982 & 16.5 & 13.5 & 17.6 & 10.4 & 22.1 & 24.4 & 18.3 & 19.0 \\ 1983 & 16.3 & 14.9 & 16.8 & 10.4 & \text { NA } & & 13.4\end{array}$

U.S. Parents and Affiliates in Developed Market Economies

\begin{tabular}{|c|c|c|c|c|c|c|c|c|c|}
\hline 1966 & 19.2 & 9.5 & 22.8 & 9.2 & 25.4 & NA & NA & 36.1 & 11.8 \\
\hline 1977 & 19.1 & 10.3 & 23.6 & 8.3 & 22.2 & 23.3 & 20.3 & 31.9 & 12.6 \\
\hline 1982 & 19.4 & 10.3 & 26.6 & 8.9 & 22.8 & 22.8 & 22.8 & 29.2 & 12.4 \\
\hline 1983 & 19.5 & 12.0 & 25.6 & 7.7 & NA & & $26.1^{d}$ & & 11.9 \\
\hline
\end{tabular}

acorresponding figure for 1982 is 18.8

bcorresponding figure for 1982 is 25.3

Corresponding figure for 1982 is 20.2

dCorresponding figure for 1982 is 25.5

Source: Appendix Tables $\mathrm{U}-3, \mathrm{U}-5$, and $\mathrm{U}-6$. 


\section{Appendix Table U-8}

Industry Distribution of Exports from the U.S. by U.S. Multinational Companies, Foreign Companies, and Other U.S. Firms, 1966, 1977, 1982, and 1983

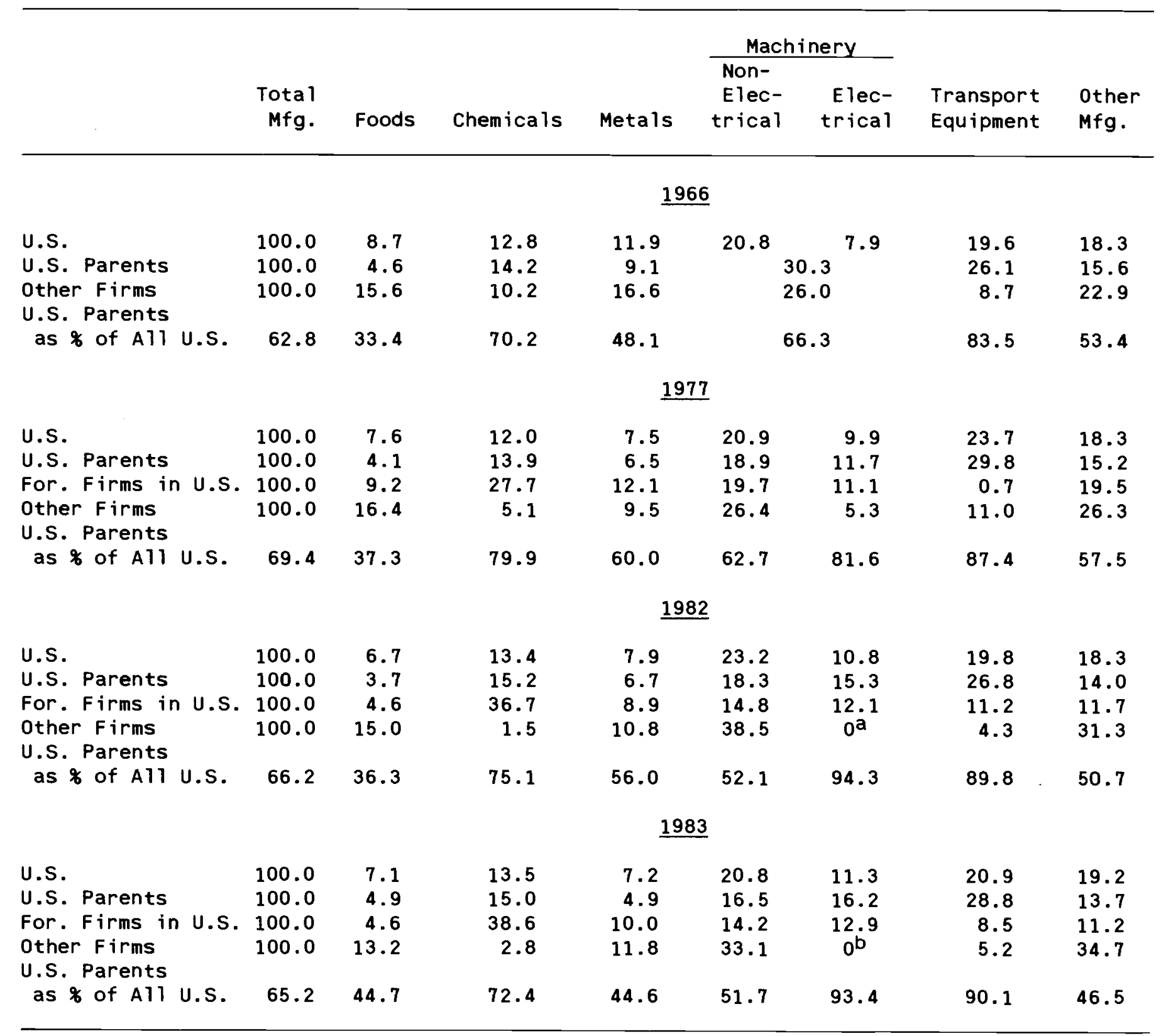

aCalculation from Appendix Table U-3 actually comes out as $-1.4 \%$.

bCalculation from Appendix Table U-3 actually comes out as $-0.9 \%$.

Source: Appendix Table U-3 
Appendix Table U-9

Industry Distribution of Exports by the U.S., U.S. Multinationals, The Wor 1d, and Developed Countries, 1966, 1977, 1982, and 1983

\begin{tabular}{|c|c|c|c|c|c|c|c|c|}
\hline \multirow[b]{2}{*}{$\begin{array}{c}\text { Total } \\
\text { Mfg. }\end{array}$} & \multirow[b]{2}{*}{ Foods } & \multirow[b]{2}{*}{ Chemicals } & \multirow[b]{2}{*}{ Metals } & \multicolumn{3}{|c|}{ Machinery } & & \\
\hline & & & & Total & $\begin{array}{l}\text { Non- } \\
\text { Elec- } \\
\text { trical }\end{array}$ & $\begin{array}{r}\text { Elec- } \\
\text { trical }\end{array}$ & $\begin{array}{l}\text { Transport } \\
\text { Equipment }\end{array}$ & $\begin{array}{l}\text { Other } \\
\text { Mfg. }\end{array}$ \\
\hline
\end{tabular}

\begin{tabular}{|c|c|c|c|c|c|c|c|c|c|}
\hline \multicolumn{10}{|c|}{$\underline{1966}$} \\
\hline Wor ld & 100.0 & 13.03 & 10.30 & 15.53 & 20.78 & 13.96 & 6.82 & 13.78 & 26.58 \\
\hline Deve1. Countries & 100.0 & 9.55 & 11.03 & 15.15 & 22.72 & 15.34 & 7.38 & 15.14 & 26.41 \\
\hline & 100.0 & 8.69 & 12.75 & 11.90 & 28.73 & 20.85 & 7.88 & 19.62 & 18.30 \\
\hline U.S. Multinat. & 100.0 & 5.74 & 13.25 & 7.32 & 29.54 & NA & NA & 27.83 & 16.33 \\
\hline \multicolumn{10}{|c|}{$\underline{1977}$} \\
\hline Wor ld & 100.0 & 11.09 & 10.73 & 13.08 & 22.71 & 13.81 & 8.90 & 17.14 & 25.25 \\
\hline Deve1. Countries & 100.0 & 8.06 & 11.52 & 13.34 & 24.42 & 15.33 & 9.09 & 18.99 & 23.68 \\
\hline U.S. & 100.0 & 7.58 & 12.04 & 7.50 & 30.87 & 20.93 & 9.94 & 23.68 & 18.34 \\
\hline U.S. Multinat. & 100.0 & 4.71 & 13.99 & 5.86 & 29.37 & 18.23 & 11.14 & 30.65 & 15.44 \\
\hline \multicolumn{10}{|c|}{$\underline{1982}$} \\
\hline Wor Id & 100.0 & 9.92 & 11.82 & 12.41 & 23.87 & 14.17 & 9.70 & 16.93 & 25.06 \\
\hline Devel. Countries & 100.0 & 8.13 & 12.47 & 12.61 & 25.27 & 15.63 & 9.64 & 18.53 & 22.99 \\
\hline U.S. & 100.0 & 6.68 & 13.35 & 7.94 & 33.96 & 23.21 & 10.75 & 19.78 & 18.30 \\
\hline U.S. Multinat. & 100.0 & 4.54 & 16.92 & 5.54 & 31.49 & 18.10 & 13.39 & 26.88 & 14.61 \\
\hline \multicolumn{10}{|c|}{$\underline{1983}$} \\
\hline Wor ld & 100.0 & 9.35 & 12.08 & 12.02 & \multirow{2}{*}{\multicolumn{4}{|c|}{$\begin{array}{l}41.29 \\
44.46\end{array}$}} & 25.17 \\
\hline Deve1. Countries & 100.0 & 7.80 & 13.11 & 11.23 & & & & & 23.40 \\
\hline U.S. & 100.0 & 7.12 & 13.49 & 7.17 & 32.16 & 20.81 & 11.34 & 20.86 & 19.21 \\
\hline U.S. Multinat. & 100.0 & 4.90 & 16.75 & 4.35 & 31.00 & 17.40 & 13.60 & 29.00 & 14.00 \\
\hline
\end{tabular}

Source: Appendix Tables $U-3, U-5$, and $U-6$

a For 1982, the breakdown of transport equipment, from the same sources, was as follows:

Motor Vehicles Other Transport

and Equipment Equipment

Wor ld

Developed Countries

11.81

13.16

10.63

5.13

U.S.

U.S. Multinationals

19.55

9.15

7.34 
Appendix Table U-10

The Universe of U.S. Parent Companies

1966, 1977, and 1982

\begin{tabular}{|c|c|c|c|c|c|c|c|c|}
\hline & \multicolumn{3}{|c|}{$\begin{array}{c}\text { Number of Reporting } \\
\text { Parent Companies }\end{array}$} & \multicolumn{3}{|c|}{$\begin{array}{l}\text { Assets of Reporting } \\
\text { Parent Companies } \\
\text { (S million) } \\
\end{array}$} & \multicolumn{2}{|c|}{$\begin{array}{l}\text { Employment of } \\
\text { Reporting } \\
\text { Parent Companies } \\
\text { (thousands) } \\
\end{array}$} \\
\hline & 1966 & 1977 & 1982 & 1966 & 1977 & 1982 & 1977 & 1982 \\
\hline All Industries & 3,354 & $3,540^{\mathrm{a}}$ & $2,245^{b}$ & 623 & 2,128 & 3,754 & 18,885 & 18,705 \\
\hline Manufacturing & 1,872 & 1,842 & 1,215 & 211 & 634 & 1,018 & 11,775 & 10,533 \\
\hline Food \& kindred prod. & 121 & 112 & 71 & 16 & 48 & 80 & 1,017 & 1,011 \\
\hline Chemicals \& allied prod. & 242 & 194 & 166 & 28 & 97 & 179 & 1,208 & 1,365 \\
\hline Primary \& fabricated metals & 270 & 277 & 170 & 33 & 87 & 115 & 1,484 & 976 \\
\hline Machinery, exc. elect. & & 323 & 213 & & 83 & 133 & 1,546 & 1,458 \\
\hline Electrical \& electronic equip. & 537 & 223 & 149 & \} 44 & 47 & 127 & 1,274 & 1,620 \\
\hline Transportation equip. & 92 & 85 & 59 & 43 & 132 & 191 & 2,289 & 1,687 \\
\hline other manuf. & 610 & 628 & 387 & 47 & 139 & 193 & 2,957 & 2,416 \\
\hline Transp. comm., public util. & 163 & 102 & 85 & 64 & 182 & 342 & 1,772 & 2,040 \\
\hline Trade & 528 & 375 & 216 & 19 & 84 & 145 & 2,472 & 2,626 \\
\hline Wholesa le & & 295 & 168 & & 27 & 43 & 271 & 397 \\
\hline Retail & & 80 & 48 & & 57 & 102 & 2,201 & 2,229 \\
\hline Finance \& insurance & 312 & 714 & 367 & 265 & 965 & 1,690 & NA & NA \\
\hline Banks & & 111 & 133 & & 585 & 1,012 & NA & NA \\
\hline others & & 603 & 234 & & 380 & 677 & 862 & 1,004 \\
\hline Mining \& smelting & 62 & 29 & 11 & 5 & 7 & 4 & 65 & 15 \\
\hline Petroleum & 145 & 158 & 143 & 51 & 219 & 487 & 891 & 1,225 \\
\hline other ind. & 472 & 320 & 208 & 9 & 37 & 70 & 1,048 & 1,262 \\
\hline Services & & 238 & 160 & & 21 & 53 & 740 & 994 \\
\hline
\end{tabular}


Sources and Notes to Appendix Table U-10

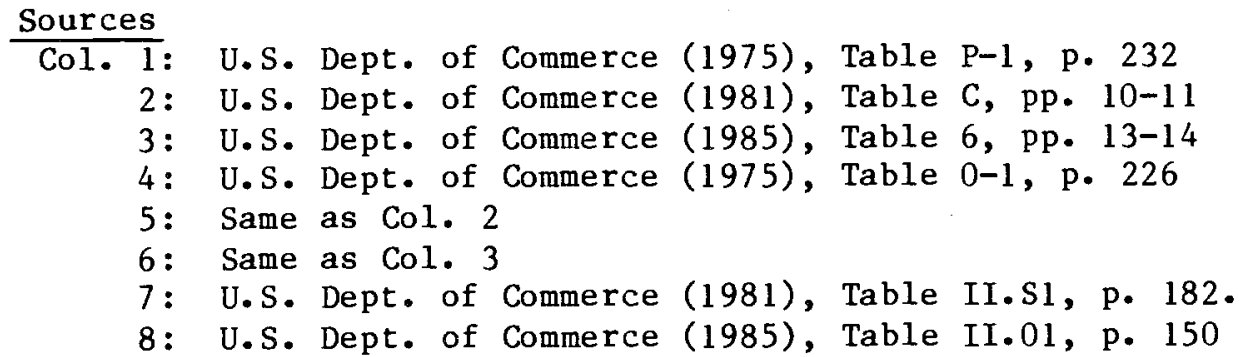

Notes

${ }^{2}$ Number of complete BE 10A reports. There were also 1,175 reporters exempt because they owned no affiliates with more than $\$ 500$ thousand in assets, sales, or net income. (U.S. Dept. of Commerce, 1981, p. 2.)

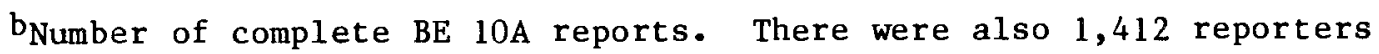
exempt because they owned no affiliates with more than $\$ 3$ million in assets, sales, or net income. (U.S. Dept. of Commerce, 1985, p. 2.) 


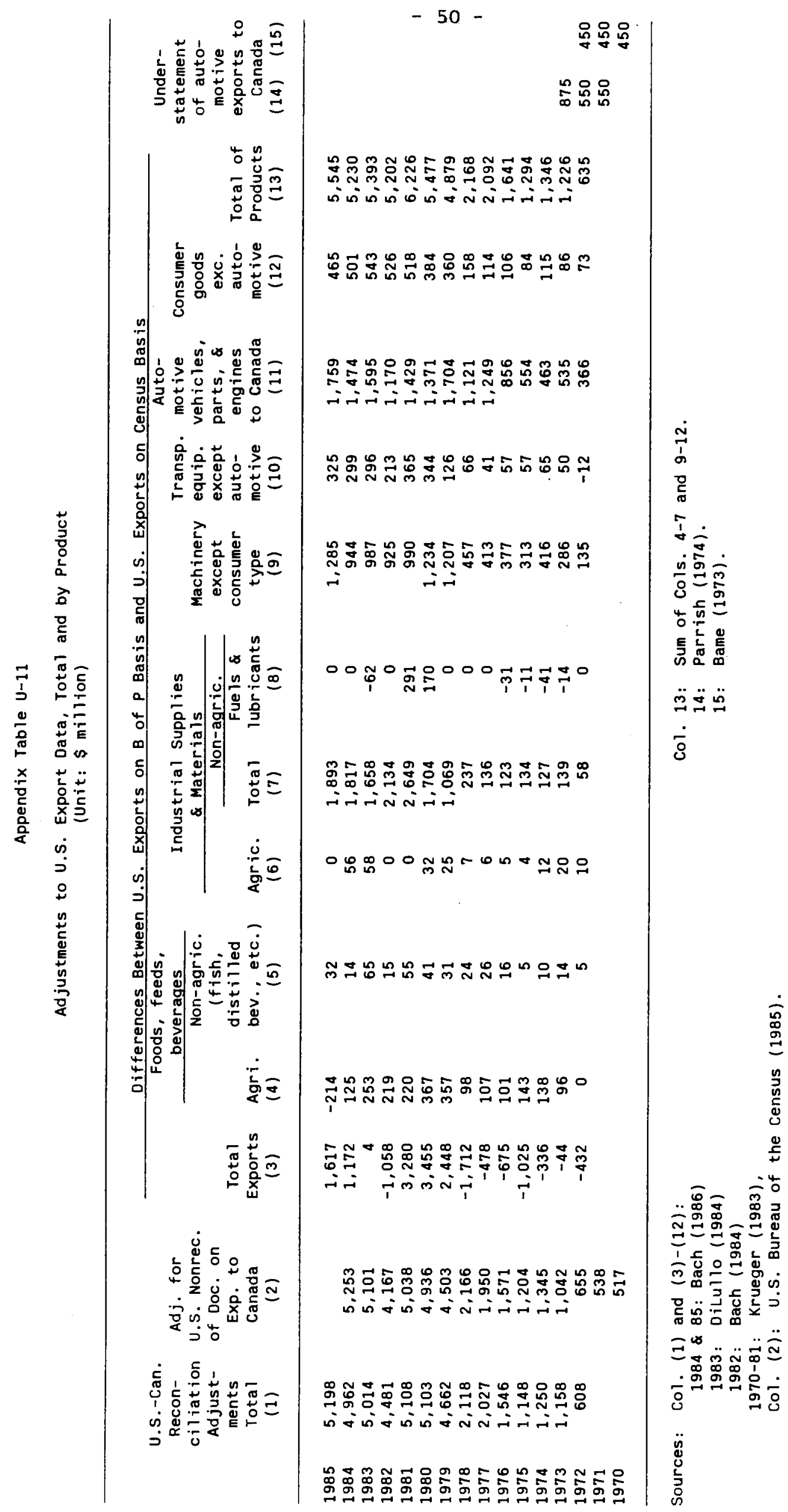


Appendix Table $U-12$

Correction of U.S. Exports for Understatement of Exports to Canada, 1970 By Broad Commodity Group and Type of Correction

(Unit: $\$$ million)

\begin{tabular}{|c|c|c|c|c|c|c|c|}
\hline \multirow[b]{2}{*}{ SITC } & \multicolumn{6}{|c|}{ Type of Correction } & \multirow[b]{2}{*}{$\begin{array}{l}\text { Total } \\
\text { Correc- } \\
\text { tion }\end{array}$} \\
\hline & $\begin{array}{l}\text { Reclassi- } \\
\text { fication } \\
\text { Type } 1\end{array}$ & $\begin{array}{l}\text { Trade } \\
\text { Defini- } \\
\text { tion } \\
\text { Type } 2\end{array}$ & $\begin{array}{l}\text { Valua- } \\
\text { tion } \\
\text { Type } 3\end{array}$ & $\begin{array}{l}\text { Nonreceipt } \\
\text { of Docu- } \\
\text { ments } \\
\text { Type } 4\end{array}$ & $\begin{array}{l}\text { Transp. } \\
\text { Charges } \\
\text { Type } 5\end{array}$ & $\begin{array}{l}\text { Errors \& } \\
\text { Timing } \\
\text { \& Other } \\
\text { Type 6 } \\
\text { \& Type 7 }\end{array}$ & \\
\hline \multicolumn{8}{|l|}{ Non-Manuf . } \\
\hline 0 & & -121 & & +17 & & +1 & -103 \\
\hline 2 & +1 & -143 & -2 & +17 & -11 & +5 & -133 \\
\hline 3 & & -79 & & & -70 & -1 & -150 \\
\hline 9 exc.fire arms & -8 & & -1 & +1 & & +9.4 & +1.4 \\
\hline Total Non-Mfg. & $\overline{-7}$ & $\overline{-343}$ & -3 & $+\overline{35}$ & $\overline{-81}$ & $+\longdiv { 1 4 . 4 }$ & -385 \\
\hline \multicolumn{8}{|l|}{ Mfrs. } \\
\hline 4 & & & & +1 & & & +1 \\
\hline 5 & & & & +46 & & -3 & +43 \\
\hline 6 & +4 & & -1 & +75 & -3 & -2 & +73 \\
\hline 67 & $(-0.2)$ & & & $(+10.2)$ & & $(-1.1)$ & $(+8.9)$ \\
\hline 68 & $(-1.3)$ & & & $(+5.7)$ & & $(-0.2)$ & $(+4.2)$ \\
\hline 69 & $(+29.6)$ & & $(-0.7)$ & $(+8.7)$ & $(-2.9)$ & $(-0.2)$ & $(+34.5)$ \\
\hline 71 & +1.2 & -1.4 & +0.6 & +95.6 & -19.7 & +13.8 & 90.1 \\
\hline 72 & +9.6 & & & +20.0 & -6.4 & -0.9 & 22.3 \\
\hline 73 & -2.4 & -13.0 & & +158.7 & -- & -2.3 & 141.0 \\
\hline 8 & -5 & -1 & -1 & +86 & -- & -2 & 77 \\
\hline 951 fire arms & & - & - & & 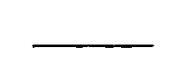 & -0.6 & -.6 \\
\hline Total Mfd. & +7 & -15.4 & 0.6 & 482.3 & -29.1 & +3.0 & +449 \\
\hline Tota 1 & -- & -358.4 & -2.4 & 517.3 & -110.1 & +17.4 & +64 \\
\hline
\end{tabular}

Source: U.S. Dept. of Commerce (1973a). 
Appendix Table U-13

Estimate of Manufactured Goods' Share of Correction for Understatement of U.S. Exports to Canada

(Unit: \$ million)

\begin{tabular}{|c|c|c|c|c|c|c|}
\hline & \multicolumn{3}{|c|}{$\begin{array}{l}\text { Reconciliation } \\
\text { Adjustment on U.S. } \\
\text { Exports to Canada }\end{array}$} & \multicolumn{2}{|c|}{$\begin{array}{l}\text { Total U.S. Exports: B. of } \\
\text { P. Bas is Minus Census Bas is } \\
\end{array}$} & \multirow[b]{2}{*}{$\begin{array}{l}\text { Manuf. Goods' } \\
\text { Share of } \\
\text { Correction } \\
\text { (per cent) } \\
\text { (6) }\end{array}$} \\
\hline & $\begin{array}{c}\text { Total } \\
\text { (1) }\end{array}$ & $\begin{array}{l}\text { Mfd. } \\
\text { Prod. } \\
(2)\end{array}$ & $\begin{array}{l}\text { For non- } \\
\text { receipt of } \\
\text { doc. by U.S. } \\
\text { (3) }\end{array}$ & 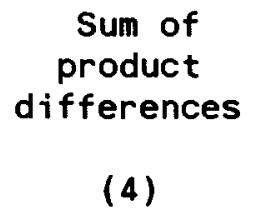 & $\begin{array}{l}\text { Differences } \\
\text { for mfd. } \\
\text { products } \\
\text { (5) }\end{array}$ & \\
\hline 1985 & 5,198 & & & 5,545 & 5,759 & 103.0 \\
\hline 1984 & 4,962 & & 5,253 & 5,230 & 5,049 & 96.5 \\
\hline 1983 & 5,014 & & 5,101 & 5,393 & 5,144 & 95.4 \\
\hline 1982 & 4,481 & & 4,167 & 5,202 & 4,983 & 95.8 \\
\hline 1981 & 5,108 & & 5,038 & 6,226 & 5,715 & 91.8 \\
\hline 1980 & 5,103 & & 4,936 & 5,477 & 4,908 & 89.6 \\
\hline 1979 & 4,662 & & 4,503 & 4,879 & 4,497 & 92.2 \\
\hline 1978 & 2,118 & & 2,166 & 2,168 & 2,063 & 95.2 \\
\hline 1977 & 2,027 & & 1,950 & 2,092 & 1,979 & 94.6 \\
\hline 1976 & 1,546 & & 1,571 & 1,641 & 1,566 & 95.4 \\
\hline 1975 & 1,148 & & 1,204 & 1,294 & 1,158 & 89.5 \\
\hline 1974 & 1,250 & & 1,345 & 1,346 & 1,237 & 91.9 \\
\hline 1973 & 1,158 & & 1,042 & 1,226 & 1,124 & 91.7 \\
\hline 1972 & 608 & 555 & 655 & 635 & 625 & 92.0 \\
\hline 1971 & & 487 & 538 & & & 98.3 \\
\hline 1970 & 64 & 444 & $517^{a}$ & & & 93.2 \\
\hline
\end{tabular}

aof which mfd. prod., 482.3.

Sources :

Cols. 1 and 3: Appendix Table U-11, Cols. 1 and 2

Col. 2: Appendix Table U-15

4: Appendix Table U-11, Col. 13

"5: Appendix Table U-11, Col. 13 minus Cols. 4, 6, and 8.

" 6: 1973-1984, Col. $5 \div$ Col. 4

1971-1972, (Col. $\div$ Col. 3) raised to the level of the 1970

figure in this column

1970, ratio for nonreceipt of documents only $(\underline{482.3})$

from Appendix Table U-12 
Appendix Table $U-14$

Estimate of Industry Distribution of Adjustment for Understatement of U.S. Exports to Canada

(Unit: $S$ million)

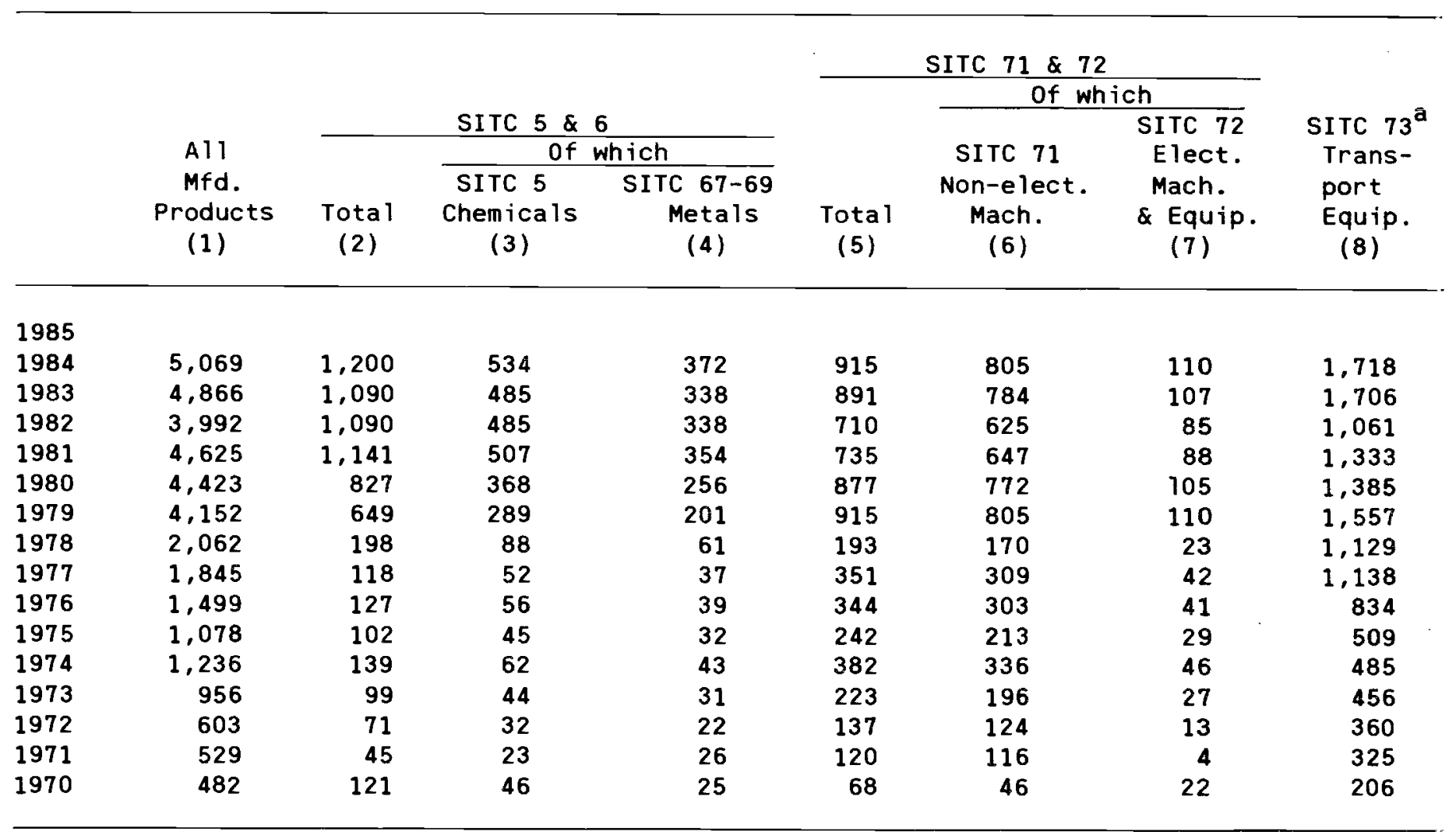

ancluding automotive engines. 
Notes to Appendix Table U-14

Co1. 1: Appendix Table U-13, Co1. 2 multiplied by Co1. 5.

Co1. 2: 1973-84, Appendix Table U-11, (Co1. 7 plus Col. 12 minus Col. 8) $\div$ Col. 13], multiplied by Col. 1 of this table and then reduced to match the estimated 1972 level.

1971-72, Appendix Table U-15, share of SITC 5 and 6 in total correction for manufactured goods, multiplied by Col. 1 of this table.

1970, Appendix Table U-12.

Co1s. 3 and 4: 1973-84, Col. 2, allocated between Chemicals and Metals by the 1972 ratio from Appendix Table U-15.

1971-72, Appendix Table U-15, shares of SITC 5 and 67-69 in correction for SITC 5 and 6 , multiplied by Col. 2 of this table and, for metals, reduced to match the 1970 level.

1970: Appendix Table U-12.

Col. 5: 1972-84, Appendix Table U-11, Co1. $9 \div$ Col. 13, multiplied by Col. 1 of this table.

1971, extrapolated from 1972 by corrections for SITC 72 plus one half of corrections for SITC 71 from Appendix Table U-15.

1970, Appendix Table U-12, corrections for SITC 72 plus one half of corrections for SITC 71 .

Co1. 6: Estimated at 88 per cent of Co1. 5 (average of 1970-72 from Appendix Tab1e U-15).

7: Estimated at 12 per cent of Col. 5 (average of 1970-72 from Appendix Table U-15).

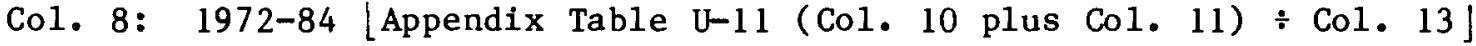
multiplied by Col. 1 of this Table.

1971, Appendix Table U-15, share of SITC 73 plus half of share of SITC 71 in total correction for manufactures, multiplied by Col. 1 of this Table.

1970, Appendix Table U-12, correction for SITC 73 plus one half of correction for SITC 71 . 
Appendix Table U-15

Correction of U.S. Exports for Understatement of Exports to Canada, 1970-72

(Unit: \$ million)

\begin{tabular}{|c|c|c|c|c|c|c|c|c|c|}
\hline & & U.S. & & & Reconcile & & Cor & rrection & \\
\hline & 1970 & 1971 & 1972 & 1970 & 1971 & 1972 & 1970 & 1971 & 1972 \\
\hline SITC & & & & & & & & & \\
\hline Non-Manuf. & & & & & & & & & \\
\hline 0 & 615.2 & 593.3 & 720.7 & 511.2 & 537.9 & 665.3 & & & \\
\hline 2 & 545.8 & 532.4 & 574.6 & 412.8 & 469.6 & 543.4 & & & \\
\hline 3 & 309.6 & 326.6 & 408.7 & 161.1 & 174.6 & 212.1 & & & \\
\hline $\begin{array}{l}9 \text { excl. } 951 \\
\text { (Firearms) }\end{array}$ & 270.4 & 303.9 & 361.2 & 275.2 & 288.0 & 311.1 & & & \\
\hline Total Non-Mfg. & $1,741.0$ & $1,756.2$ & $2,065.2$ & $1,360.3$ & $1,470.1$ & $1,731.9$ & -380.7 & -286.1 & -333.3 \\
\hline Manuf. & & & & & & & & & \\
\hline 1 & 9.2 & 10.4 & 11.5 & 9.3 & 10.8 & 10.9 & & & \\
\hline 4 & 22.8 & 26.7 & 21.3 & 24.1 & 27.7 & 23.4 & & & \\
\hline 5 & 619.3 & 659.4 & 764.5 & 661.7 & 681.0 & 793.5 & +42.4 & +21.6 & +29.0 \\
\hline 6 & $1,162.4$ & $1,301.2$ & $1,580.6$ & $1,234.4$ & $1,321.3$ & $1,616.8$ & +72.0 & +20.1 & +36.2 \\
\hline 67 & $(264.5)$ & $(271.0)$ & $(302.6)$ & $(273.4)$ & $(271.3)$ & $(302.5)$ & $(+8.9)$ & $(+.3)$ & $(-.1)$ \\
\hline 68 & $(129.3)$ & $(140.0)$ & $(162.1)$ & $(133.5)$ & $(140.1)$ & $(163.1)$ & $(+4.2)$ & $(+.1)$ & $(+1.0)$ \\
\hline 69 & $(252.4)$ & $(276.0)$ & $(338.0)$ & $(286.9)$ & $(322.1)$ & $(375.6)$ & $(+34.5)$ & $(+46.1)$ & $(+37.6)$ \\
\hline 71 & $1,864.1$ & $2,124.6$ & $2,614.5$ & $1,954.0$ & $2,211.3$ & $2,695.6$ & +89.9 & +86.7 & +81.1 \\
\hline 72 & 614.8 & 740.9 & 890.6 & 637.0 & 744.7 & 903.8 & +22.2 & +3.8 & +13.2 \\
\hline 73 & $2,447.4$ & $3,069.9$ & $3,688.5$ & $2,588.4$ & $3,326.1$ & $3,983.2$ & +141.0 & +256.2 & +294.7 \\
\hline 8 & 588.0 & 651.1 & 755.0 & 664.0 & 710.6 & 854.7 & & & \\
\hline 951 (Firearms) & 15.0 & 25.5 & 23.7 & 14.4 & 25.5 & 23.7 & & & \\
\hline Total Mfg. & $7,343.0$ & $8,609.7$ & $10,350.2$ & $7,787.3$ & $9,097.0$ & $10,905.6$ & +444.3 & +487.3 & +555.4 \\
\hline TOTAL & $9,084.0$ & $10,365.9$ & $12,415.4$ & $9,147.6$ & $10,567.1$ & $12,637.5$ & +63.6 & +201.2 & +222.1 \\
\hline
\end{tabular}

Source: U.S. Department of Commerce (1973b) 
Appendix Table U-16

Relative U.S. Price Levels

Index of U.S. Export Prices

Relative to

Major Industrial Exporters $(1975=100)$

\begin{tabular}{|c|c|}
\hline \multicolumn{2}{|c|}{$\frac{(1975=100)}{(1)}$} \\
\hline $\begin{array}{l}1953 \\
1954\end{array}$ & $\begin{array}{l}113.6 \\
116.4\end{array}$ \\
\hline 1955 & 117.5 \\
\hline 1956 & 121.3 \\
\hline 1957 & 124.7 \\
\hline 1958 & 128.3 \\
\hline 1959 & 131.8 \\
\hline 1960 & 133.7 \\
\hline 1961 & 133.6 \\
\hline 1962 & 135.5 \\
\hline 1963 & 135.6 \\
\hline $\begin{array}{l}1964 \\
1965\end{array}$ & $\begin{array}{l}135.2 \\
133.9\end{array}$ \\
\hline 1966 & 133.5 \\
\hline 1967 & 137.9 \\
\hline 1968 & 143.5 \\
\hline 1969 & 144.5 \\
\hline 1970 & 137.6 \\
\hline 1971 & 134.6 \\
\hline 1972 & 123.8 \\
\hline 1973 & 109.8 \\
\hline 1974 & 103.5 \\
\hline 1975 & 100.0 \\
\hline 1976 & 104.4 \\
\hline 1977 & 101.8 \\
\hline 1978 & 91.8 \\
\hline 1979 & 87.0 \\
\hline 1980 & 86.9 \\
\hline 1981 & 102.5 \\
\hline 1982 & $115.4^{\mathrm{a}}$ \\
\hline 1983 & $123.2^{\circ}$ \\
\hline
\end{tabular}

axtrapolated from 1981 by U.S. GDP price level relative to those of 9 other industrial countries. These are absolute price levels for each year. For further explanation, see Table 1 of Kravis and Lipsey (1986). Figures for 1981-83 are:

$\begin{array}{rr}1981 & 97.6 \\ 1982 & 109.8 \\ 1983 & 117.3\end{array}$

Sources:

Col. 1: Index of U.S. export prices for commodities of SITC 5-8, weighted by 1975 U.S. exports, relative to those of 7 other developed countries, also weighted by 1975 U.S. exports. For a further description of the data, see Bushe, Kravis, and Lipsey (1986). 